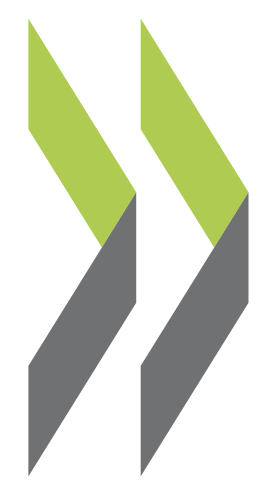

OECD Economics Department Working Papers No. 846

To Move or not to Move: What Drives Residential Mobility Rates in the OECD?

\section{Aida Caldera Sánchez,} Dan Andrews 
Organisation de Coopération et de Développement Économiques

Organisation for Economic Co-operation and Development

18-Feb-2011

ECONOMICS DEPARTMENT

English - Or. English

TO MOVE OR NOT TO MOVE: WHAT DRIVES RESIDENTIAL MOBILITY RATES IN THE OECD?

ECONOMICS DEPARTMENT WORKING PAPERS No.846

By Aida Caldera Sánchez and Dan Andrews

All Economics Department Working Papers are available through OECD's internet web site at www.oecd.org/eco/working papers

JT03296643

Document complet disponible sur OLIS dans son format d'origine

Complete document available on OLIS in its original format 


\section{ABSTRACT/RESUMÉ \\ To move or not to move: what drives residential mobility rates in the OECD?}

Residential mobility is closely tied to housing market forces and has important implications for labour mobility and the efficient allocation of resources across the economy. This paper analyses patterns of residential mobility across OECD countries and the role of housing policies in enhancing or hampering residential mobility. Based on cross-sectional household data for 25 countries, the results suggest that differences in residential mobility across countries are partially related to differences in public policies. After controlling for household and country-specific characteristics, residential mobility is higher in countries with lower transaction costs, more responsive housing supply, lower rent controls and tenant protection. Residential mobility tends also to be higher in environments with greater access to credit, suggesting that financial deregulation - by lowering borrowing costs and facilitating access to mortgage finance - facilitates mobility. This cross-country evidence is supported by city and state-level evidence for the United States, which also highlights the potential risks that high leverage rates pose to residential mobility.

JEL classification codes: R23; R31; R21; R38; H20.

Keywords: Housing markets; residential mobility; transaction costs; rental market regulations.

$+++++++++$

Déménager ou ne pas déménager: quels sont les déterminants des taux de mobilité résidentielle dans l'OCDE?

La mobilité résidentielle est étroitement liée aux dynamiques du marché du logement et a des implications importantes pour la mobilité professionnelle et la répartition efficace des ressources dans l'économie. Ce document analyse les tendances de la mobilité résidentielle dans les pays de l'OCDE et le rôle des politiques du logement dans le renforcement ou l'obstruction de la mobilité résidentielle. Sur la base des enquêtes auprès des ménages pour 25 pays, les résultats indiquent que les différences dans la mobilité résidentielle entre les pays sont en partie liées aux différentes politiques des gouvernements. Après avoir contrôlé pour les caractéristiques du ménage et celles propres à chaque pays, la mobilité résidentielle est plus élevée dans les pays où les coûts de transaction, le contrôle des loyers et la protection des locataires sont plus faibles, et l'offre de logements plus elevée. La mobilité résidentielle est aussi plus élevée dans les environnements avec un plus grand accès au crédit, ce qui suggère que la déréglementation financière - en réduisant les coûts d'emprunt et en facilitant l'accès au financement hypothécaire - facilite la mobilité. Ces résultats sont soutenus par une analyse au niveau ville et États pour les États-Unis, qui met également en évidence les risques potentiels que posent un taux d'endettement élevé à la mobilité résidentielle.

Classification JEL : R23; R31; R21; R38; H20.

Mots-clés: Marché du logement; mobilité résidentielle; coûts de transaction; régulation du marché locataire.

Copyright OECD 2011

Application for permission to reproduce or translate all, or part of, this material should be made to: Head of Publications Service, OECD, 2 rue André-Pascal, 75775 Paris CEDEX 16. 


\section{TABLE OF CONTENTS}

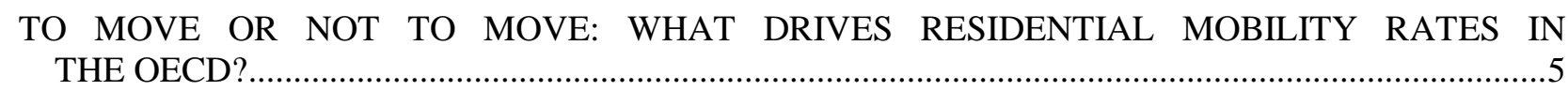

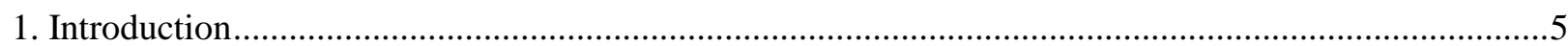

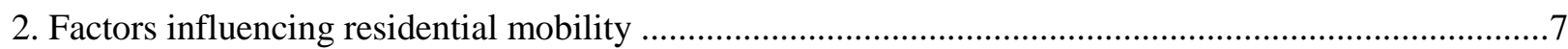

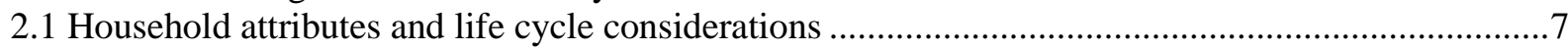

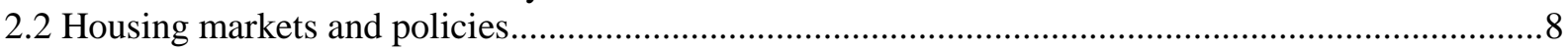

2.3 Effect of policies beyond the housing market on residential mobility .........................................10

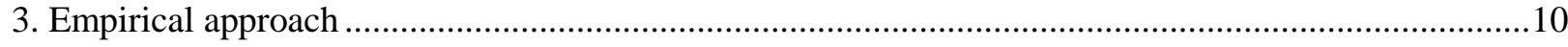

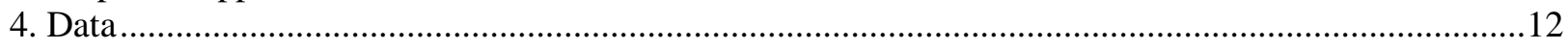

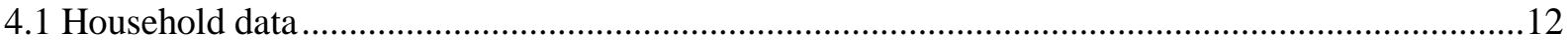

4.2 Patterns of residential mobility across countries .........................................................................13

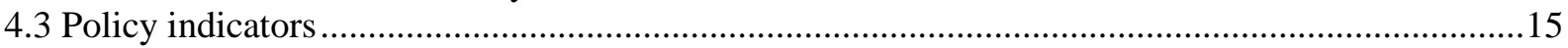

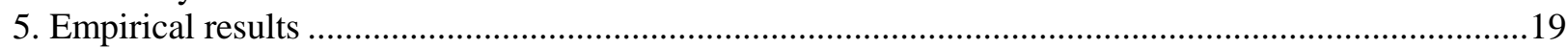

5.1 The effects of household characteristics on residential mobility ................................................19

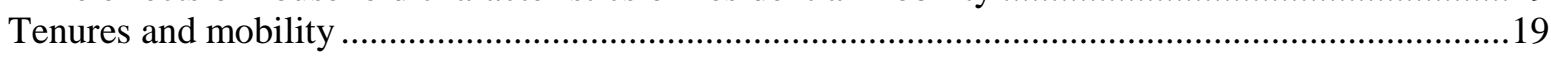

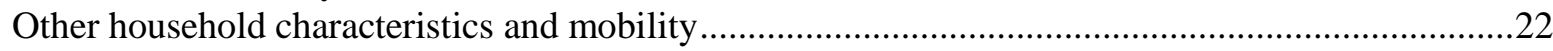

5.2 The effect of policy-related factors on residential mobility …......................................................23

Do policy-related factors affect differently the mobility of young versus old households? ..............25

5.3 City-level evidence on the effect of policies on residential mobility .............................................26

6. Economic significance of the effect of policy-related factors on mobility .........................................28

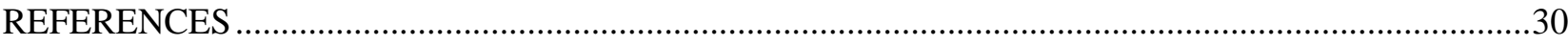

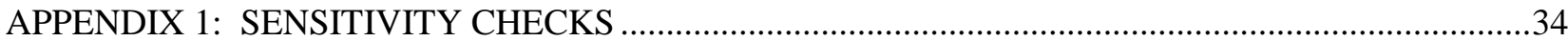

\section{Tables}

1. The effect of household characteristics on residential mobility........................................................19

2. The effect of policy related factors on residential mobility ...............................................................24

3 . The effect of policy related factors on residential mobility on old versus young households..............26

4. The effect of policies on United States city residential mobility .........................................................27

1A. Correlation between different policies and policy related factors.....................................................35

2A. Sensitivity check: large country bias, country sample size equal to Portugal....................................35

3A. Sensitivity check: large country bias, country sample size equal to Luxembourg.............................36

4A. Sensitivity check: large country bias, country sample size equal to Switzerland ...............................37

5A. Sensitivity check: including several policies in the cross-country model.........................................38 


\section{ECO/WKP(2011)15}

\section{Figures}

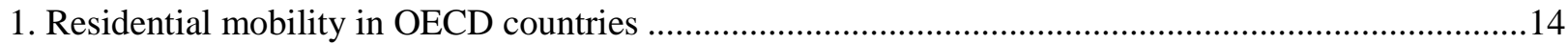

2. Breakdown of residential mobility rates by reasons to move ........................................................15

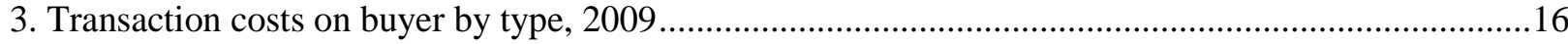

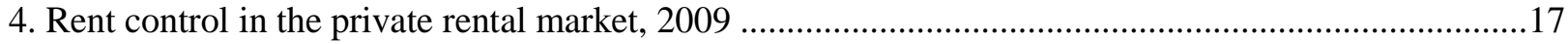

5. Tenant-landlord regulations in the private rental market, 2009 ......................................................17

6. Price responsiveness of housing supply: selected OECD countries …...........................................18

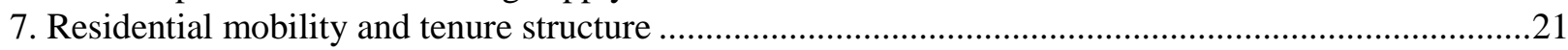

8. Residential mobility rate and share of households in negative equity ............................................28

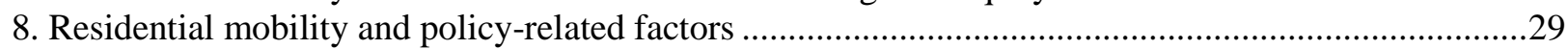


ECO/WKP(2011)15

\title{
TO MOVE OR NOT TO MOVE: WHAT DRIVES RESIDENTIAL MOBILITY RATES IN THE OECD?
}

\author{
By Aida Caldera Sánchez and Dan Andrews ${ }^{1}$
}

\section{Introduction}

1. This paper analyses patterns of residential mobility across OECD countries and the role of housing policies in enhancing or hampering residential mobility. Residential mobility is closely tied to housing market forces and has important implications for labour mobility and the efficient allocation of resources across the economy. When institutional constraints or other barriers impede residential mobility, the allocating role of housing markets is disrupted. Countries with low rates of residential mobility may suffer from higher housing price volatility (Englund and Ioannides, 1993) if due to high transaction costs households cannot immediately react to price changes by changing their residence. Low rates of residential mobility can be an obstacle to labour adjustment, making labour markets less efficient and, therefore, can adversely affect overall economic performance (Hardman and Ioannides, 1999; Oswald, 1996). A low degree of residential mobility also has other economic costs since it reduces the speed of an economy's adjustment to shocks (Blanchard and Katz, 1992). On the other hand, excessive residential mobility may have adverse implications for social stability within neighborhoods by depreciating local social capital (David et al. 2010) or for the educational performance of children if forced to change schools too often (Ersing et al., 2009). The optimal rate of residential mobility cannot, nevertheless, be identified from crosscountry comparisons as it depends on country/region specific characteristics.

2. The empirical analysis in this paper aims at disentangling the drivers of residential mobility and understanding the extent to which socio-economic household characteristics and housing policies affect residential mobility across OECD countries. The analysis uses household micro datasets containing extensive information on household attributes, which allows investigation of the drivers of the household decision to move for a large number of OECD countries, including 23 European countries, Australia and the United States. ${ }^{2}$ In addition, the analysis builds on newly-constructed, cross-country comparable indicators in three key housing policy areas, namely transaction costs, rent control and tenant protection, as well as on new comparable estimates of the price elasticity of housing supply in OECD countries.

$1 \quad$ Corresponding authors are: Aida Caldera Sánchez (Aida.CalderaSanchez@oecd.org) and Dan Andrews (Dan.Andrews@oecd.org) both at the OECD Economics Department. The authors would like to thank Kwame Donaldson, Jørgen Elmeskov, Åsa Johansson, Giuseppe Nicoletti and Jean-Luc Schneider for their valuable comments and Catherine Chapuis for excellent statistical work, as well as Irene Sinha for excellent editorial support. The views expressed in this paper are those of the authors and do not necessarily reflect those of the OECD or its member countries.

2 Residential mobility refers in this paper to the change of dwelling. A distinction between different types of moves, such as regional or inter country moves, is not possible due to data limitations. 
3. Results suggest that differences in residential mobility across countries are associated with differences in government intervention. After controlling for household and country-specific characteristics, residential mobility is higher in countries with lower transaction costs, more responsive housing supply, lower rent controls and tenant protection, as well as greater access to credit - as measured by the share of private credit to GDP available in the economy. This cross-country evidence is supported by city-level evidence for the United States. Mobility is higher in cities with less restrictive land-use regulation and rent controls and where there is more competition in banking and, thus, possibly greater access to credit.

4. More specifically, a number of observations can be made:

- Mobility tends to be relatively high in the Nordic countries, Australia and the United States, while it is much lower in Eastern and southern European countries. Empirical cross-country estimates of the determinants of residential mobility show that the probability of moving decreases with householders' age and with living in cohabitation, while it increases with educational attainment and migrant status.

- In general, homeowners, in particular outright owners, are less mobile than private renters.

- In most countries, residential mobility is lower among households living in social or subsidised housing relative to private tenants, possibly reflecting that such tenants may have to give up their below-market rents if they move. ${ }^{3}$ Within the group of social/subsidised tenants mobility is particularly low in countries where social housing is more targeted to those with the greatest need (e.g. Australia, France and the United Kingdom). Despite the fact that highly-targeted systems have the advantage of selecting individuals based on their means, compared to broad-based systems where everyone has access to social housing, this finding suggests that if targeted systems are not well designed, they may cluster relatively disadvantaged and/or financiallyconstrained households for whom moving then becomes comparatively difficult.

- Higher transaction costs in buying and selling a property are associated with lower residential mobility, particularly for younger households. Additionally, higher rent controls and greater security of tenure are also associated with lower residential mobility.

- A more responsive housing supply is associated with higher residential mobility. The magnitude of this effect seems to be fairly large, with greater benefits for the mobility of younger households. This finding has policy implications to the extent that differences in housing supply responsiveness reflect policies regulating the use of land and rental markets as well as urban and geographical characteristics (Caldera Sánchez and Johansson, 2011).

- Residential mobility tends to be higher in environments with greater access to credit. Evidence suggests that higher volumes of private credit to GDP in the economy and lower down-payment constraints are associated with higher residential mobility. This implies that financial deregulation can ease credit constraints by lowering the cost of loans and promoting access to housing finance to a wider set of the population, thereby increasing residential mobility. The evidence further suggests that younger households benefit more from greater access to credit in terms of mobility. The recent experience in the United States, however, highlights the potential risks that very high leverage poses to mobility. 
5. The remainder of the paper is organised as follows. Section 2 presents a framework for analysing the drivers of residential mobility. Section 3 presents the empirical framework. Section 4 describes the data used in the empirical analysis, paying particular attention to the description of the novel indicators measuring structural features of housing markets in the OECD. Section 5 presents the results, while Section 6 investigates the economic significance of the effects of policies on mobility.

\section{Factors influencing residential mobility}

6. There is a combination of microeconomic and macroeconomic reasons why people move that vary depending on the time period and household characteristics. Household attributes, the household course of life and job career patterns determine the propensity to move and the choice of dwelling (Dieleman, 2001). In addition, household mobility is strongly related to housing market conditions and economic circumstances at the local and national levels.

7. Economic theory predicts that the decision to move will depend on the fixed costs of moving, compared to the net present value of the gains in the alternative location (e.g. Sjaastad, 1962; Mincer, 1978; Bartel, 1979). Following Bartel (1979), in a discrete choice model, the household decision is determined by the discounted net return from moving at time $t$. If this return is positive, then the household will move:

$$
\operatorname{Pr}_{t}=f\left(G_{t}\right)
$$

where $\operatorname{Pr}_{t}$ is the probability that the individual moves at time $t$ and $G_{t}$ are the discounted net returns from moving, where $G_{t}$ can be written as follows:

$$
G_{t}=Y_{t} *-Y_{t}-C_{t}
$$

with $Y_{t}^{*}$ the present value of the expected real income stream if the individual moves at $t, Y_{t}$ is the present value of the expected real income stream in the current location at time $t$, and $C_{t}$ are the costs of moving. The costs of moving can be thought of being composed of pecuniary and non-pecuniary costs (Sjaastad, 1962). Pecuniary costs include the out-of-pocket expenditure involved in moving, such as searching for a new dwelling and a job in the new location and the transaction costs involved in the process of moving. Non-pecuniary costs include foregone earnings and the costs of changing one's environment, such as the costs of uprooting school-age children or of giving up the returns on location-specific investments. If $\mathrm{G}_{\mathrm{t}}>0$, the individual will migrate.

\subsection{Household attributes and life cycle considerations}

8. Mobility studies condition the decision to move on a household's characteristics influencing the gains/costs of moving, that is the net returns as given by Equation (1). The decision to move has been shown to be closely tied to events in a person's life, such as family formation, dissolution and, in particular, job changes (e.g. Dieleman, 2001). Earlier research has shown that changing jobs over a long distance naturally requires a residential move (e.g. Clark and Withers, 1999) and that the decision to change jobs is closely tied to moving decisions (e.g. Bartel, 1979). In this sense, household characteristics influencing potential earnings in a different location, such as education, influence the discounted net return from moving. For instance, education should have a positive effect on the probability of moving since more highly-educated individuals tend to have better information about non-local job opportunities and, thus, may be more adaptable to change (Bartel, 1979).

9. Other household characteristics, such as size, marital status and age, also determine the decision to move. For example, households with more than one member in the labour force should have higher costs 
of moving than independent households comprising a single person (e.g. Bartel, 1979; Mincer, 1978). Similarly, households with school-age children should have lower net return from migration because of the costs of uprooting school-age children. In the same vein, younger households are most likely to move because they have fewer location-specific investments that tie them down to a location and have longer time horizons in which to amortise the costs of moving; therefore, relatively small gains in earnings may make them move. Indeed, existing evidence confirms that in most countries, young adults between the ages of 20 and 35 are by far the most mobile segments of the population (e.g. Dieleman, 2001).

10. Empirical evidence further suggests that there are a number of major elements of the housing bundle that are critical to the mobility decision (e.g. Dieleman, 2001). These include the price, tenure of the dwelling and its location with respect to workplaces and services. House prices and rents, as long as they influence the cost of living, will influence the household's decision to move. However, in practice, many households are likely to be credit-rationed, with their mortgage capped as a proportion of their earnings (Bover et al. 1989). Empirical evidence in fact suggests that homeowners tend to have longer residential spells and much lower mobility rates than renters (e.g. Tatsimaros, 2009). One explanation is that homeowners face higher search and transaction costs and, therefore, tend to spend relatively longer spells in their residence in order to spread such costs over a longer time period (e.g. Coulson and Fisher, 2009). A complementary explanation of this finding is that housing is an illiquid asset and in cyclical downturns higher real interest rates and falling house prices may lock-in homeowners (Green and Hendershott, 2001). Theoretical evidence further suggests that the quality of services close to the dwelling influences the mobility decision. For instance, parents may move to make sure that their children attend a good school (Fack and Green, 2010). And, in consequence, this search for high quality schools increases the prices of housing close to them (e.g. Gibbons and Machin, 2003 and 2006).

\subsection{Housing markets and policies}

11. The matching of households and dwellings is not only determined by households' attributes or the bundle of housing services that each dwelling represents. Household reallocation is strongly linked to housing market conditions at the local and national levels and influenced by government policies that shape housing market outcomes. For instance, changes in the housing market, such as periods of falling house prices, may influence the relative return of different locations and housing policy interventions, such as for instance taxation, influence the opportunity costs of moving and thus mobility rates.

12. Housing is an investment, as well as being a consumption good, and residential mobility can be linked to portfolio adjustment considerations. Existing evidence suggests that episodes of falling housing prices are associated with decreasing levels of market transactions and lower residential mobility (Henley, 1996). Economic research provides a number of explanations. First, a rational response of homeowners is to hold on to existing housing investments in anticipation of positive expected future returns (Case and Schiller, 1988). Second, negative equity holdings (i.e. the value of the outstanding loan is greater than the estimated value of the house) may also prevent homeowners from moving. During a housing market bust, homeowners suffering severe house price declines and having mortgage balances higher than the value of their home will find it difficult to sell their home, repay their mortgage and provide a down-payment for a new home, thereby becoming locked-in. Chan (2001) finds that a housing downturn can lead to substantial lock-in effects and reduced residential mobility, particularly because of the dominance of housing in the household asset portfolio.

13. Theoretical and empirical studies have shown that transaction costs may create lock-in effects in the housing market and have negative effects on residential and job mobility, thereby increasing unemployment (Oswald, 1996, 1999; Van Ommeren and Van Leuvensteijn, 2005). To a large extent transaction costs, in a similar way as stamp duties and registration taxes, are directly determined by government fiscal policies. Government policies also influence the fees to be paid to intermediaries, i.e. 
lawyers or real estate agents, which are set directly by government regulations (or professional self-backed regulations endorsed by the government) or influenced by market entry regulations. Several studies further suggest that capital gains taxation of owner-occupied housing, which works as transaction tax if levied upon realisation, results in lock-in effects for homeowners (Cunningham and Engelhardt, 2007; Sinai, 1998). In addition, many countries have some form of tax treatment that favours owner occupancy relative to other housing tenures, which influences the opportunity cost of housing investment. This favourable treatment of owner occupation may reduce residential mobility as it can tilt housing consumption towards owner occupancy away from renting, thereby squeezing the rental sector.

14. The rental sector is an important part of the housing market as it adds flexibility to the market and facilitates the reallocation between different tenures. Because rental markets are characterised by asymmetric information between landlords and tenants and other potential market failures, many countries have a range of controls and regulations in both private and social rental markets (Andrews et al., 2011). These regulations range from rent controls to rules concerning the duration and termination of contracts and the reasons for tenant eviction. Although these regulations typically aim at addressing market failures and provide security of tenure, they may have the effect of decreasing residential mobility, especially when they are too strict. A large body of research suggests that stringent regulations can discourage new construction and delay maintenance by capping the price of rentals and lowering the returns on investment, thereby reducing both the size and variety of services in the rental sector (Sims, 2007; Arnott, 2003). In addition, several studies provide evidence that renters in rent-controlled housing markets move less frequently and consume less than optimal quantities of housing (e.g. Clark et al. 1982; Linneman, 1983; Lind, 2001). For instance, if rents in rent-regulated dwellings are set, or vary differently from nonregulated dwellings, rent regulation may limit residential mobility as sitting tenants in rent-controlled dwellings will be reluctant to move and give up their below-market rents (e.g. European Housing Review, 2009). This lower residential construction and reduced mobility of incumbent tenants may lead to lower entry into and exit from the rent-regulated rental sector, leading to lower residential mobility.

15. Similarly, housing subsidies may lock-in tenants if households who enjoy a subsidy in their present accommodation are less mobile due to additional moving costs associated with losing the subsidy (Henley, 1996). Hughes and McCornick $(1981,1985)$ analyse the interregional migration patterns in the United Kingdom using cross-section data and find that social housing tenants are significantly less likely to move over long distances than owner occupiers. More recently, Menard and Sellem (2010) present descriptive evidence for France, which further suggests that social housing tenants are, on average, less mobile than tenants in the private market. However, the association of social housing with residential moves is not clear-cut because social housing is generally associated with individual characteristics that may generate lower mobility, such as shorter job tenures (Hughes and McCormick, 1997). Despite the potentially negative effects of rent regulations and social housing on mobility some regulation may be needed to avoid a too high turnover in the housing market that may lead to social losses (David et al. 2010; Janiak and Wasmer, 2008). For instance, evidence by Ersing et al. (2009) suggests that residential reallocation is often associated with academic problems for children. A residential change can create stress for children who face adjusting to new living space and integrating into a new neighbourhood and possibly a new school.

16. A crucial factor that can influence households' mobility is how responsive housing supply is to changes in demand. In particular, the price-elasticity of housing supply determines to what extent demand shocks, such as financial deregulation or population growth, lead to an adjustment in housing construction as opposed to adjustments in prices. Differences in supply response between areas can drive a wedge in prices and have a negative impact on household location decisions if, for instance, homeowners living in highly-priced supply constrained areas are reluctant to move to lower-priced areas for fear of being priced out the market (e.g. Barker, 2004; Cameron and Mullbauer, 1998). Housing market interventions which limit the supply of housing, such as restrictive land use regulations and building codes can impede housing 
markets in reaching a competitive equilibrium and therefore constraint housing supply and household mobility. Caldera Sánchez and Johansson (2011) indeed find that housing supply responsiveness tends to be lower in countries where it takes longer to acquire a building permit.

\subsection{Effect of policies beyond the housing market on residential mobility}

17. To the extent that housing markets have multiple interactions with the rest of the economy, policies and institutions affecting other markets can indirectly affect residential mobility in a number of ways.

18. Financial and mortgage markets may affect household mobility through their effect on borrowing costs. Given that owner-occupied housing generally requires debt financing, the existence of liquidity constraints may force some households to remain in the rental market when they could optimally choose to be homeowners. The process of financial deregulation observed in recent years has significantly lowered borrowing costs and resulted in a substantial expansion in the supply of mortgage loans in many countries, thereby easing financial constraints and promoting access to housing finance to a wider set of the population (Andrews et al., 2011). This general relaxation in borrowing constraints may have particularly facilitated the transition from rental to owner occupation for credit-constrained households, leading to higher residential mobility. On the other hand, financial deregulation may have increased household vulnerability to shocks and the risks that households find themselves in negative equity positions which, as discussed above, may have adverse effects on mobility.

19. Labour market institutions influence labour mobility and can have important effects on residential mobility. Institutions, such as stringent labour protection, high unemployment benefits, wage co-ordination or weak active labour market policies, have been found to be associated with lower labour mobility and employment rates, potentially leading to lower residential mobility. ${ }^{4}$ For instance, it has been argued that the generosity of unemployment insurance may play a key role in regional migration patterns. Hassler et al. (2005) argue that unemployment insurance deters mobility because, given that mobility is costly, agents who are well insured against the risk of unemployment will have lower incentives to move in order to regain employment. In support of this argument, existing evidence suggests that intra-country migration responds significantly to temporary regional shocks in the United States, but not in Europe where unemployment insurance schemes are more comprehensive (Blanchard and Katz, 1992; Decressin and Fatas, 1995).

20. On the other hand, social policies, like unemployment benefits, may increase the degree of residential mobility by relaxing current financial constraints and providing insurance against unexpected income losses. By increasing resources of those unemployed, unemployment benefits may increase residential mobility and help to finance labour search and moving costs, as found by a recent study by Tatsiramos (2009). And evidence by Bassanini et al. (2010) shows that unemployment benefit generosity appears to have a positive impact on average gross worker flows.

\section{Empirical approach}

21. In order to investigate the factors influencing residential mobility in OECD countries, a two-step approach is adopted. First, the effect of household characteristics, such as tenure, income and age, on residential mobility is estimated. This exercise is important to determining whether the effects of household attributes on mobility vary across countries.

$4 \quad$ Wage co-ordination makes moving less desirable as there are fewer incentives to move to areas with potentially higher wages because wage differences are squeezed by collective contracts. For a review of this literature, see Bassanini and Duval (2006) and Blanchard and Wolfers (2000). 
22. The following model of the decision to move is estimated country-by-country:

$$
\operatorname{Pr}_{i c}=\Phi\left(\beta_{0}+\beta_{1} H_{i c}+\gamma_{r}+u_{i c}\right)
$$

where $\phi$ is the normal distribution, i denotes household, c denotes country, and $\operatorname{Pr}_{\text {ic }}$ denotes the probability that the household head i moves. The advantage of this country-by-country estimation is that it allows abstracting from common macro factors affecting household decisions within a country and focusing on household-driven determinants of the decision to move.

23. The explanatory variables include a vector of demographic and economic household characteristics, $\mathrm{H}$, which are likely to influence residential mobility. These include tenure status (categorical variable measuring if the head of household is an outright owner, owner with a mortgage, tenant in the private sector or social/subsidised tenant), age category (24-34, 35-44, 45-54, 55-66), education (categorical variable measuring if the head of household has low, middle, or high levels of education), employment status ( 1 if unemployed and 0 if employed), marital status ( 1 if the head of household is married, 0 otherwise), nationality ( 1 if foreign citizen and 0 if national), household income and its square to control for non-linear effects, household size, household satisfaction with the dwelling (categorical variable measuring whether household is very dissatisfied, sufficiently dissatisfied, satisfied or very satisfied), and the degree of urbanisation in the area where the household lives. ${ }^{5}$ Finally, $\gamma$ are regional fixed effects and $u$ captures individual random shocks. ${ }^{6}$

24. In a second step, the empirical approach exploits cross-country variation in policies and institutions to assess the role of policy settings in explaining residential mobility. As discussed in Section 2, certain policies may reinforce or mitigate residential mobility. For instance, higher transaction costs, tighter rent controls and greater tenant protection may either increase the actual costs or decrease the incentives to move, thereby curbing mobility. Policies covered by the analysis include housing market policies that influence the amount of transaction costs in moving and rental regulations capping rents and determining the degree of tenant protection. An additional important factor considered is the responsiveness of housing supply to price signals, which is partially policy-driven by land use and planning regulations (Caldera Sánchez and Johansson, 2011). In addition, the effect of broader policies influencing housing affordability, such as access to credit and unemployment benefits is also assessed.

25. The following cross-country specification is estimated:

$$
\operatorname{Pr}_{i c}=\Phi\left(\alpha+\beta P_{c}+H_{i c} \phi+C_{c} \Gamma+e_{i c}\right)
$$

where $\phi$ is the normal distribution, $\operatorname{Pr}_{i c}$ is the probability to change residence for household head $\mathrm{i}$ in country c; P denotes country-specific housing policies or policy related factors, like the responsiveness of housing supply, that may influence the decision to move, $\mathrm{H}$ denotes household characteristics (e.g. tenure type, education, age, income). The vector $\mathrm{C}$ controls for other country-specific factors that may influence

\footnotetext{
$5 \quad$ The age of the head of household may partially control for length of residence in the current location and path dependence, which is known to be a strong determinant of mobility (Hassler et al. 2005). The longer an individual lives in a location the stronger is his/her attachment to it. In addition, the variable age cohort 55-66 may pick up the effect of retirement on the probability to move.

For more than half of the countries in the sample there are no available data on household location. The degree of urbanisation may serve in such a case as a plausible control for regional differences.
} 
residential mobility, including the degree of urbanisation and total household income. ${ }^{7}$ Finally, $e$ is an error term capturing shocks affecting the household decision to move.

26. The estimation of equation (4) treats policies as exogenous factors influencing mobility abstracting from some possible endogeneity concerns. However, institutions cannot be taken as exogenous. For instance, low residential mobility may prompt governments to design policies to address it. Or citizens may vote for governments that implement policies discouraging mobility in order to satisfy their preferences. However, the lack of plausible instruments and time series data on some of the policies make it difficult to control for omitted variables that may influence both residential mobility and policies and could potentially lead to a spurious relationship between policies and residential mobility. A possible solution would be to use country-fixed effects to wash out time-invariant, country-specific factors. The drawback from that approach is that in the cross-section approach used here the effect of the policy variables of interest, $\mathrm{P}$, would no longer be identified.

\section{Data}

27. Two types of data are employed in the analysis. First, household survey data are drawn from household surveys in each of the OECD member countries for which household data are available. Second, data on policies are mainly drawn from OECD newly-constructed, cross-country comparable indicators on housing policies, complemented with other publicly-available data.

\subsection{Household data}

28. The empirical analysis uses household data for 25 OECD countries from different sources. The advantage of these household datasets is that they are based on representative random samplings of the countries' populations and include information on residential moves, i.e. change of dwellings, as well as on household socio-economic characteristics, allowing analysis of the drivers of residential mobility. Household data for 22 European countries comes from the European Union Statistics on Income and Living Conditions (EU-SILC) household database. ${ }^{8}$ The analysis focuses on the 2007 cross-section, which in that year contains a specific module on household housing conditions, including information on change of dwelling and the reasons for doing so.

29. The data for European countries is complemented with household data for Australia, Switzerland and the United States for the year 2007. The Australian data come from the Household, Income and Labour Dynamics in Australia (HILDA) survey, a household panel survey collecting information about economic and subjective wellbeing, labour market dynamics and family dynamics of Australian households. The American data is collected from the American Housing Survey (AHS), which collects data on US housing and household characteristics, as well as recent movers. And the Swiss data come from the Swiss Household Panel (SHP), which is an annual panel study following a random sample of households in Switzerland over time.

\footnotetext{
7 This cross-country specification does not include regional fixed-effects because of the missing data on household location for many countries.

The EU-SILC dataset includes the following 23 countries: Austria, Belgium, Czech Republic, Denmark, Estonia, Finland, France, Germany, Greece, Hungary, Iceland, Ireland, Italy, Luxembourg, the Netherlands, Norway, Poland, Portugal, Slovak Republic, Slovenia, Spain, Sweden and the United Kingdom. Poland is not included in the empirical analysis because inspection of the dataset revealed a large number $(35 \%)$ of households that were living in accommodation for free, which is not representative of the population.
} 
30. The sample used in the analysis covers individuals aged 24 to 66 in order to exclude atypical moving choices and excludes those for whom accommodation is provided free of cost to avoid the empirical results being influenced by atypical tenure status. The final data sample consists of some 120000 observations in 25 countries. ${ }^{9}$

\subsection{Patterns of residential mobility across countries}

31. Residential mobility varies widely across countries. Figure 1 shows average residential mobility rates within countries defined as the percentage of households that changed residence within the two years preceding the survey. Mobility is highest in the Nordic countries (29\% in Iceland, 23\% in Sweden, 21\% in Norway, $19 \%$ in Finland, 18\% in Denmark), Australia (24\%) and the United States (21\%), while is low in southern and Eastern European countries (4\% in Slovenia, Slovak Republic, Poland, 5\% in Czech Republic and Portugal, $8 \%$ in Greece and Spain, and 9\% in Italy).

32. This evidence is in line with previous studies. Janiak and Wasmer (2008) show that, while relative to the United States, average mobility rates tend to be low in EU15 countries, the differences are largest with Southern European countries and much smaller with Nordic countries. Rupert and Wasmer (2009) argue that the disparities in average mobility rates between the United States and Europe can be explained by higher commuting costs (e.g. petrol tax, price of cars and car insurance) and frictions in the housing market, such as rental housing market regulations, which tend to be stricter in Europe. With respect to Eastern European countries, other studies suggest that the very low mobility rates observed in these countries could be accounted for by labour market rigidities (Boeri and Terrell, 2002), but also by the very specific features of housing markets in these countries (Fidrmuc, 2004). Compared to other countries, those in Eastern Europe generally display a high share of owner-occupied housing, a small private rental sector and persistent under-supply of new residential housing (Andrews et al., 2011; Bloze, 2009). These high ownership rates stem from a rapid privatisation of publicly-owned properties in these countries through the sale of dwellings to tenants at low prices during the transition to market economies in the 1990s.

9 Unfortunately the dataset does not allow for distinguishing between local residential moves and long distance residential moves. Local residential moves typically involve a change in the residence but not in the working place, whereas regional or within-country moves are typically linked to job reasons (Clark et al. 1999). 


\section{Figure 1: Residential mobility in OECD countries ${ }^{1}$}

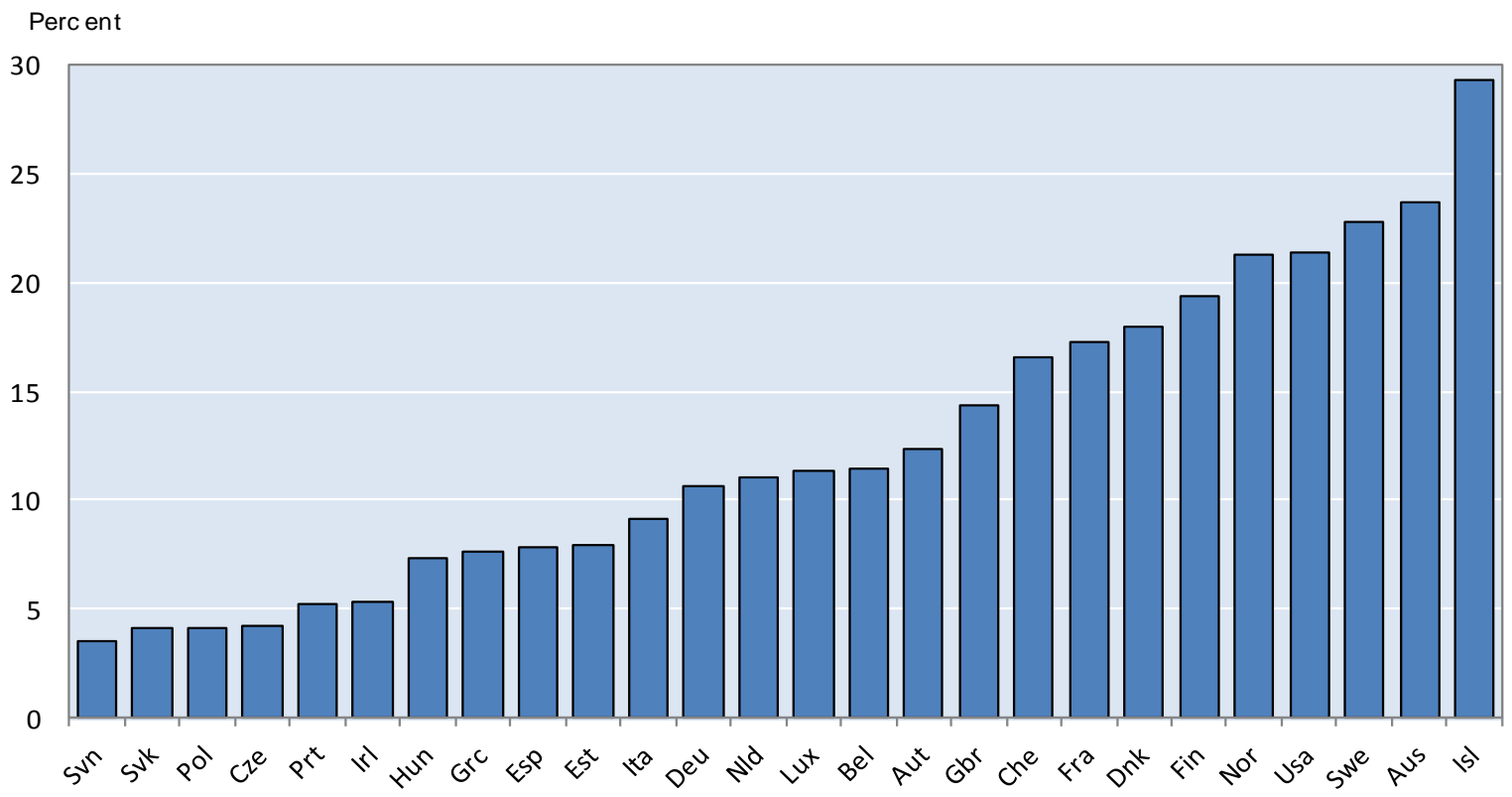

1. The low mobility rate in some Eastern European countries (e.g. $4 \%$ in Slovenia implying a move every 50 years) does not seem reasonable and may reflect problems with the underlying data. However, this is difficult to verify as there is no alternative data source.

Sources: OECD calculations based on 2007 EU-SILC Database, on HILDA for Australia, AHS for the United States, SHP for Switzerland.

33. Figure 2 shows the breakdown of residential mobility by reasons for moving. It distinguishes between four main reasons: family, employment, housing-related and other reasons. ${ }^{10}$ In most countries the majority of moves are accounted for by housing-related reasons (37\% on average) or family-related reasons (32\% on average), whereas employment-related reasons account for a much smaller share of, on average, $9.5 \%$. As expected the proportion of moves due to job-related reasons is greater in large countries such as the United States, Australia, Italy or the United Kingdom, while tending to be lesser in smaller countries like the Netherlands, Switzerland and Belgium. In small countries, commuting may be a preferred option in the event of changing jobs rather than that of residential reallocation, which is relatively more costly and influenced by imperfections in housing markets.

Family-related reasons relates to a change in the marital or partnership status, establish own household, to follow partner/parents or to obtain better school or care facilities for children or other dependants. Job reasons include: starting a new job, transfer of existing job, looking for work, easier commuting, redundancy or retirement. Housing-related reasons include: desire to change tenure status, wanting a new or better apartment, and seeking a better neighbourhood (less crime, more facilities etc.). 
Figure 2: Breakdown of residential mobility rates by reasons to move

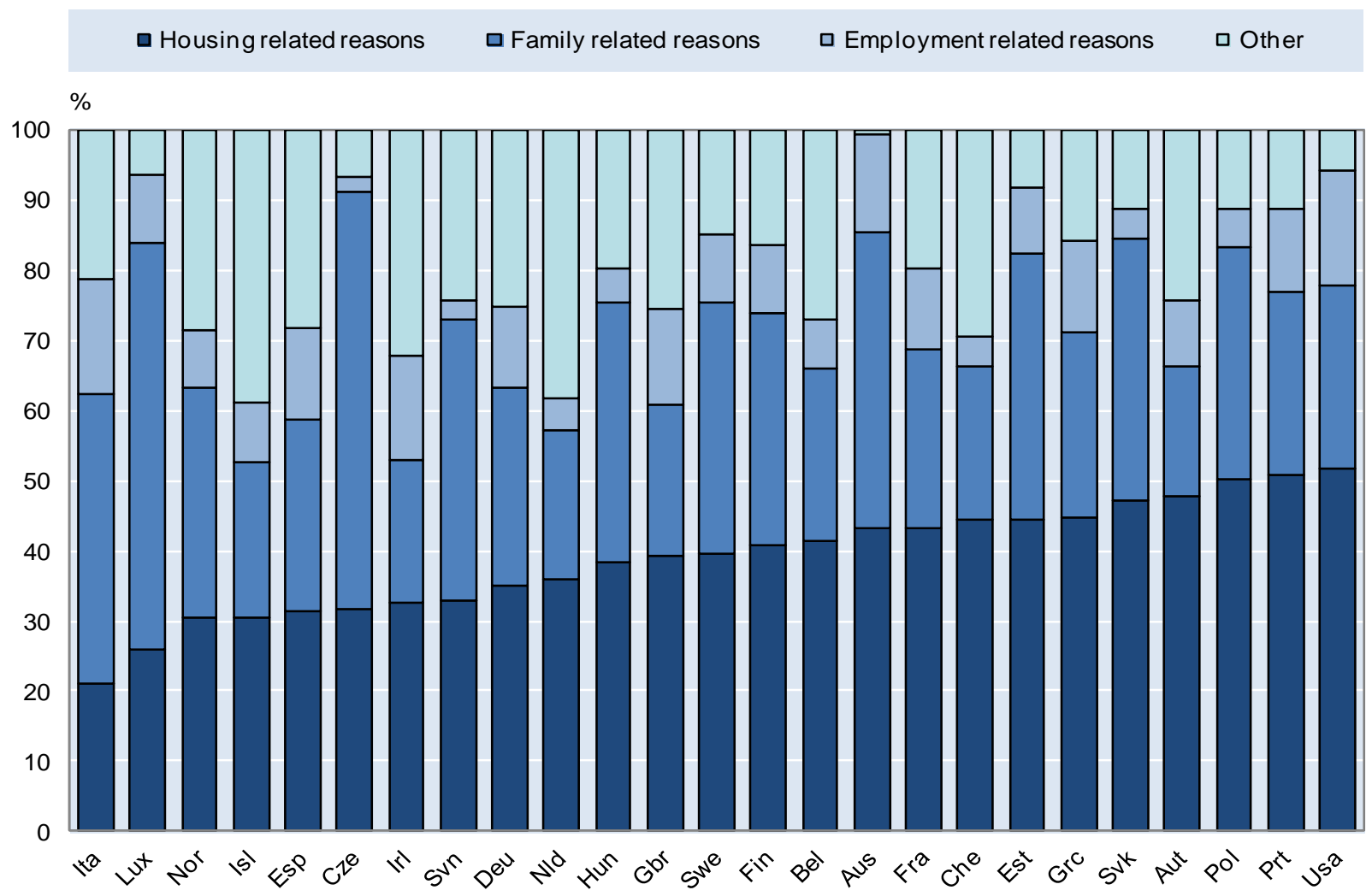

Source: OECD calculations based on 2007 EU-SILC Database, on HILDA for Australia, AHS and Rupert and Wasmer (2009) for the United States, SHP for Switzerland.

\subsection{Policy indicators}

34. Housing policy interventions are widespread in OECD countries. They include fiscal measures such as taxes and direct provision of social housing, as well as various regulations aimed at influencing housing market outcomes in terms of prices, rents, quantity, quality and allocation of dwellings. Despite the existence of such widespread interventions in most countries, little cross-country, comparable information exists as to the extent of these policies. This paper exploits newly-constructed, cross-country comparable indicators in three key housing policy areas: transaction costs, rental regulations and tenant protection arrangements in the private rental sector (See Andrews et al., 2011; Johansson, 2011).

35. The transaction costs indicator includes a number of different types of costs and fees, such as transfer taxes (e.g. stamp duties), registration fees incurred when registering the property in the land registry, notarial or other legal fees and typical real estate agency fees (see Johansson (2011) for details). The majority of these costs tend to fall on the buyer and, as shown in Figure 3, differ considerably across countries. 
Figure 3: Transaction costs on buyer by type, $2009^{1}$

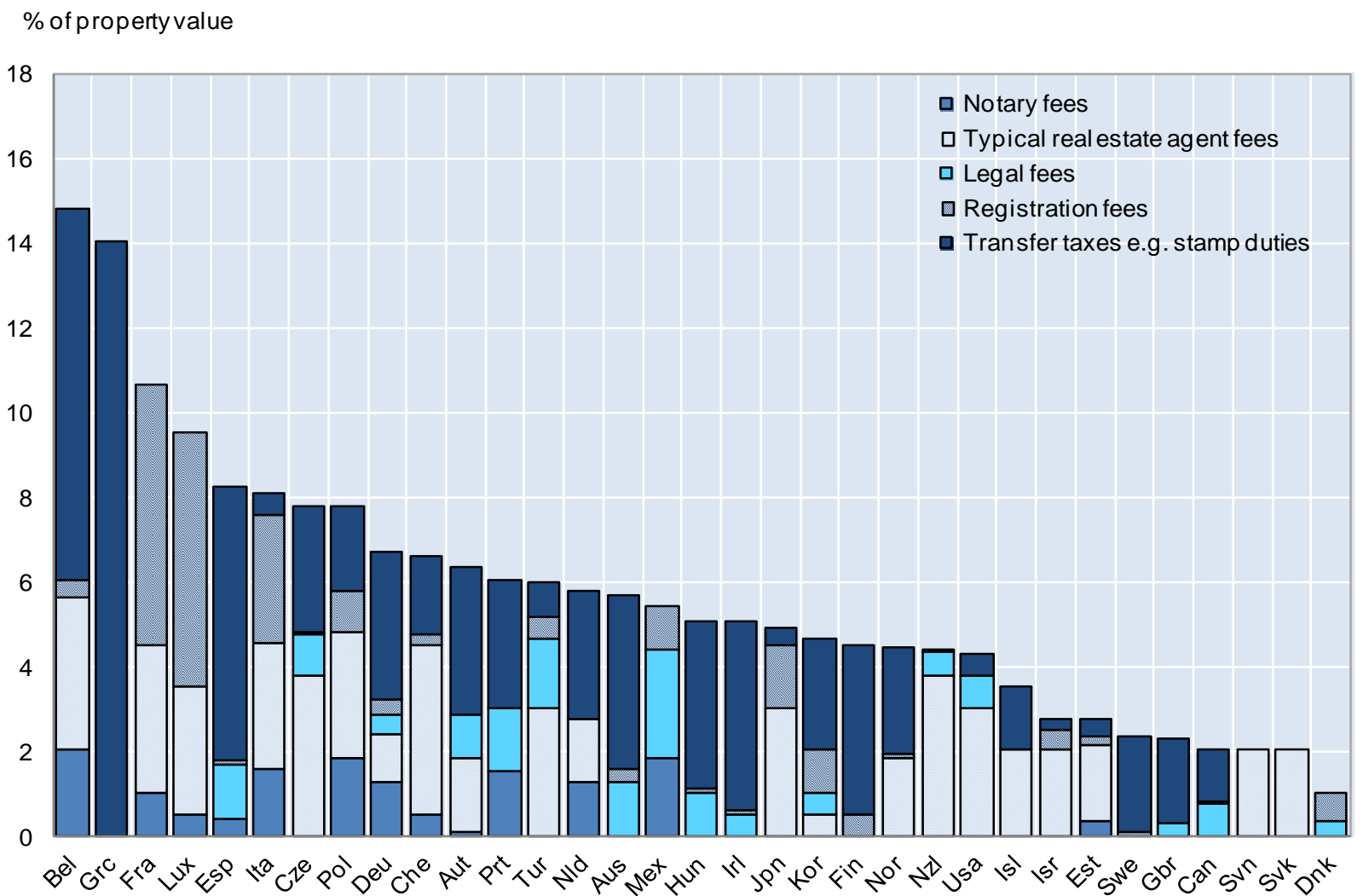

1. Transaction costs refer to average costs. See Johansson (2011) for details.

Source: Calculations based on the OECD Housing Market questionnaire.

36. The rent regulation indicator measures the extent of rent control, covering regulations setting limits on rents and rent increases, including the pass through of costs onto rents. Rent controls appear to be comparatively strict in countries with a relatively large rental sector (e.g. Sweden, the Netherlands, Germany and Czech Republic) while, on the other hand, rent controls are lax in New Zealand, Finland, Slovenia, the United Kingdom and the United States (Figure 4). The tenant protection indicator covers regulations governing tenant-landlord relations, such as rules regulating tenure security, tenant eviction procedures and deposit requirements, which vary markedly across countries (Figure 5). 
Figure 4: Rent control in the private rental market, $2009^{1}$

Scale 0-6: Increasing in degree of control

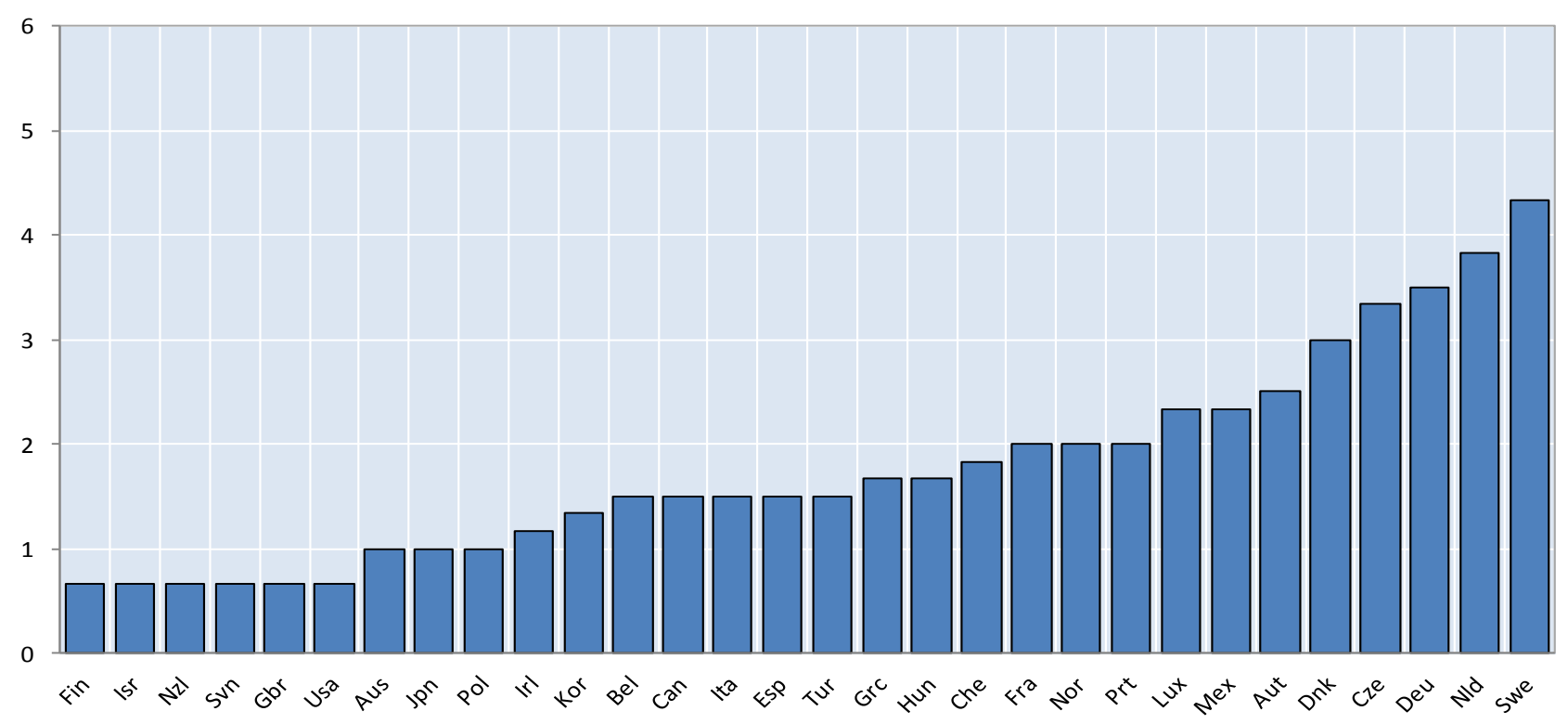

1. This indicator is a composite indicator of the extent of controls of rents, how increases in rents are determined and the permitted cost pass-through onto rents in each country. See Johansson (2011) for details.

Source: Calculations based on the OECD Housing Market questionnaire.

\section{Figure 5: Tenant-landlord regulations in the private rental market, $2009^{1}$}

\section{Scale 0-6: Increasing in protection for tenants}

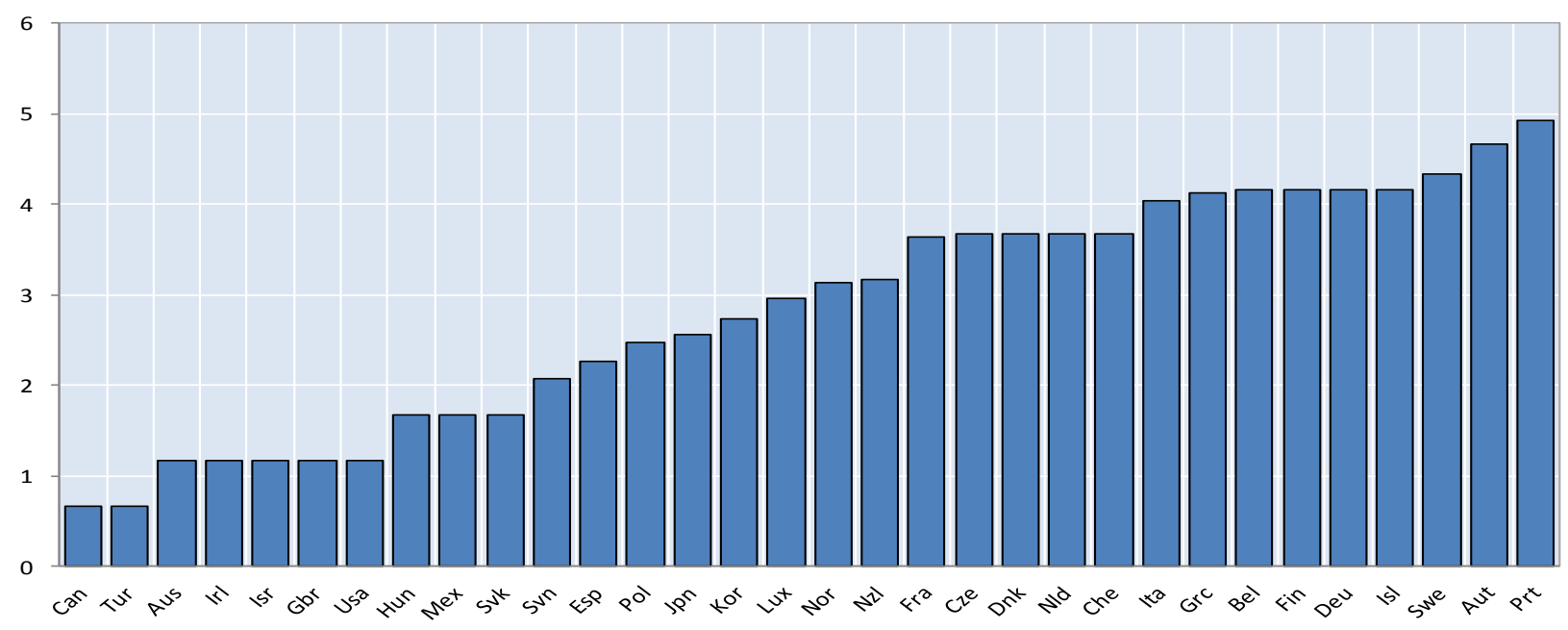

1. The indicator measures the extent of tenant-landlord regulation within a tenancy. It includes the ease of evicting a tenant, degree of tenure security and deposit requirements. See Johansson (2011) for details.

Source: Calculations based on the OECD Housing Market Questionnaire.

37. In addition to these newly-built indicators the empirical analysis uses recent, comparable estimates of the long-run price responsiveness of new housing supply sourced from Caldera Sánchez and Johansson (2011). As shown in Figure 6, housing supply responsiveness varies substantially across 
countries. It tends to be comparatively high in North America and some Nordic countries (Sweden and Denmark), while it is lower in continental European countries and in the United Kingdom. Caldera Sánchez and Johansson (2011) show suggestive evidence that cumbersome land use and planning regulations are associated with a less responsive housing supply in the long run across OECD countries.

Figure 6: Price responsiveness of housing supply: selected OECD countries

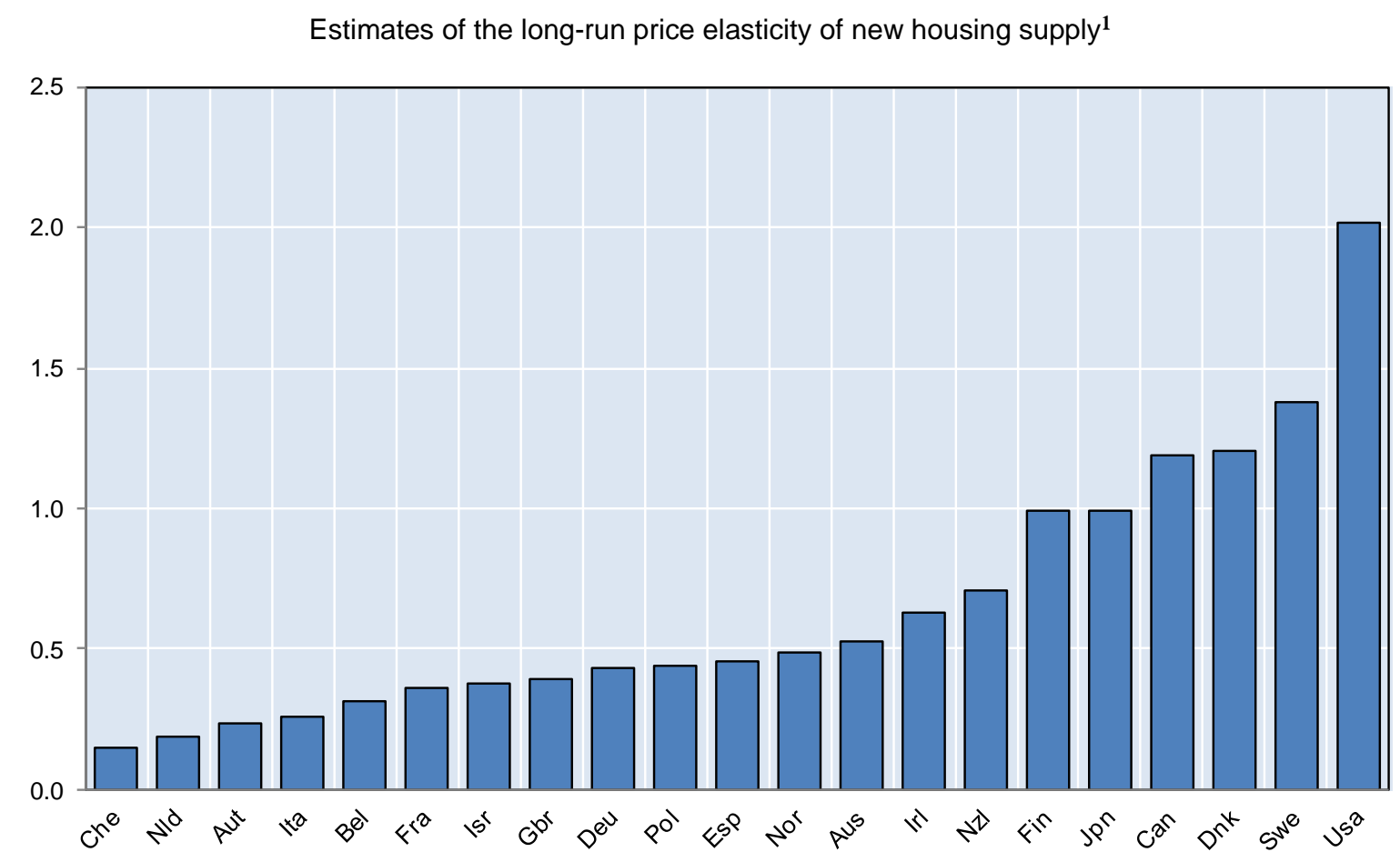

1. Estimates of the long-run elasticity of new housing supply where new supply is measured by residential investment. All elasticities are significant at least at the $10 \%$ level. In the case of Spain, restricting the sample to the period 1995-2007, which would reflect recent developments in housing markets (such as the large stock of unsold houses resulting from the construction boom starting in 2000 and peaking in 2007-09), only slightly increases the estimate of the elasticity of housing supply from 0.45 to 0.58. Estimation period 1980s to early 2000s. For more detail see Caldera Sánchez and Johansson (2011).

Source: OECD estimates.

38. To complement the information on housing market policies, data on credit market institutions and labour market policies are also used. First, the share of private credit to GDP, sourced from the IMF, measures how much private credit the financial system lends to firms and individuals. Second, the loan-tovalue ratio, (LTV), sourced from the ECB (2009), measures the ability of mortgage markets to ensure households access to financing and captures the extent of the down-payment constraint, which is particularly relevant for the marginal buyer. Finally, the income-supporting features of the unemployment system are measured by the long-term average unemployment net benefit replacement rate for a single person with social assistance and having been unemployed for 5 years (OECD, Benefits and Wages Database). ${ }^{11}$

11 The choice of this indicator is motivated on the grounds that the benefit for this target group is the least generous, therefore providing a stricter test of the effect of unemployment insurance on mobility. 


\section{Empirical results}

39. This section first reports the empirical results of the effect of household characteristics on residential mobility country-by-country. It then moves on to the results of the effects of policies on residential mobility across countries and cities in the United States. The results are robust to a number of sensitivity checks reported in the Appendix.

\subsection{The effects of household characteristics on residential mobility}

40. Table 1 reports the country-by-country results of estimating Equation 3. The reported coefficients are marginal effects and can be interpreted as changes in mobility rates. These changes are relative to mobility of the excluded household group: young, national, single tenants in the private rental market who are both highly-educated and dissatisfied with their residence.

\section{Tenures and mobility}

41. A first finding is that in most OECD countries homeowners are less mobile than private renters. The coefficients on the homeowner dummies are negative and highly significant, indicating that relative to tenants in the private sector market (the excluded category) homeowners are less mobile. A common explanation for this finding is that homeowners face higher search and transaction costs than private tenants when considering moving to a new residence (e.g. Oswald, 1996).

Table 1: The effect of household characteristics on residential mobility ${ }^{1}$

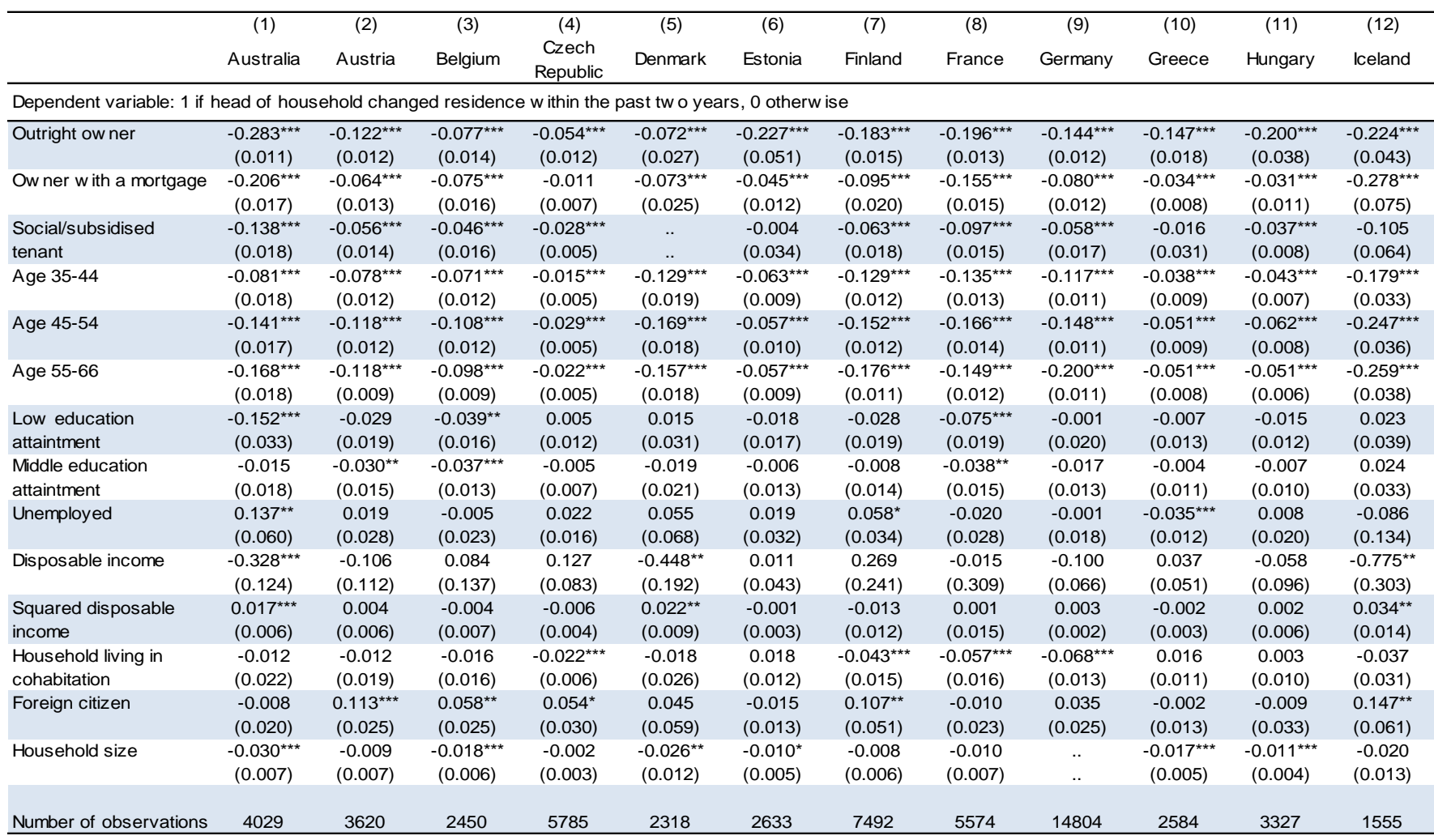


Table 1: The effect of household characteristics on residential mobility ${ }^{1}$ (cont'd)

\begin{tabular}{|c|c|c|c|c|c|c|c|c|c|c|c|}
\hline & $\begin{array}{c}(13) \\
\text { Ireland }\end{array}$ & $\begin{array}{l}(14) \\
\text { Italy }\end{array}$ & $\begin{array}{c}(15) \\
\text { Luxembourg }\end{array}$ & $\begin{array}{c}(16) \\
\text { Norw ay }\end{array}$ & $\begin{array}{c}\text { (17) } \\
\text { Portugal }\end{array}$ & $\begin{array}{c}(18) \\
\text { Slovak } \\
\text { Republic } \\
\end{array}$ & $\begin{array}{l}\text { (19) } \\
\text { Spain }\end{array}$ & $\begin{array}{c}(20) \\
\text { Sw eden }\end{array}$ & $\begin{array}{c}(21) \\
\text { Sw itzerland }\end{array}$ & $\begin{array}{c}\text { (22) } \\
\text { United } \\
\text { Kingdom }\end{array}$ & $\begin{array}{c}(23) \\
\text { United } \\
\text { States } \\
\end{array}$ \\
\hline \multicolumn{12}{|c|}{ Dependent variable: 1 if head of household changed residence $w$ ithin the past tw $o$ years, 0 otherw ise } \\
\hline Outright ow ner & $\begin{array}{c}-0.090^{\star \star \star} \\
(0.017)\end{array}$ & $\begin{array}{c}-0.085^{\star \star \star} \\
(0.012)\end{array}$ & $\begin{array}{l}-0.027 \\
(0.029)\end{array}$ & $\begin{array}{c}-0.147^{\star \star \star} \\
(0.024)\end{array}$ & $\begin{array}{c}-0.074^{\star \star \star} \\
(0.013)\end{array}$ & $\begin{array}{c}-0.064^{\star \star \star} \\
(0.014)\end{array}$ & $\begin{array}{c}-0.135^{\star \star \star} \\
(0.014)\end{array}$ & $\begin{array}{c}-0.114^{\star \star \star} \\
(0.020)\end{array}$ & $\begin{array}{c}-0.114^{\star \star \star} \\
(0.020)\end{array}$ & $\begin{array}{c}-0.111^{\star \star \star} \\
(0.014)\end{array}$ & $\begin{array}{c}-0.197^{\star \star \star} \\
(0.004)\end{array}$ \\
\hline Ow ner w ith a mortgage & $\begin{array}{c}-0.052^{\star \star \star} \\
(0.015)\end{array}$ & $\begin{array}{c}-0.048^{\star \star \star} \\
(0.009)\end{array}$ & $\begin{array}{l}-0.043 \\
(0.028)\end{array}$ & $\begin{array}{c}-0.170^{\star \star \star \star} \\
(0.040)\end{array}$ & $\begin{array}{c}-0.036^{\star \star \star} \\
(0.008)\end{array}$ & $\begin{array}{l}0.022^{*} \\
(0.013)\end{array}$ & $\begin{array}{c}-0.072^{\star \star \star} \\
(0.013)\end{array}$ & $\begin{array}{c}-0.105^{\star \star \star} \\
(0.020)\end{array}$ & $\begin{array}{l}-0.037^{\star} \\
(0.020)\end{array}$ & $\begin{array}{c}-0.134^{\star \star *} \\
(0.023)\end{array}$ & $\begin{array}{c}-0.216^{\star \star \star} \\
(0.006)\end{array}$ \\
\hline $\begin{array}{l}\text { Social/subsidised } \\
\text { tenant }\end{array}$ & $\begin{array}{c}-0.017^{\star \star \star} \\
(0.005)\end{array}$ & $\begin{array}{c}-0.043^{\star \star \star *} \\
(0.013)\end{array}$ & $\begin{array}{c}-0.090^{\star \star \star} \\
(0.015)\end{array}$ & $\begin{array}{l}-0.063 \\
(0.042)\end{array}$ & $\begin{array}{c}-0.029^{\star \star \star} \\
(0.005)\end{array}$ & $\begin{array}{l}-0.014 \\
(0.011)\end{array}$ & $\begin{array}{c}-0.041^{\star \star \star} \\
(0.007)\end{array}$ & $\begin{array}{c}0.000 \\
(0.056)\end{array}$ & $\begin{array}{c}0.035 \\
(0.068)\end{array}$ & $\begin{array}{c}-0.092^{\star \star \star} \\
(0.014)\end{array}$ & $\begin{array}{c}-0.059^{\star \star \star *} \\
(0.010)\end{array}$ \\
\hline Age $35-44$ & $\begin{array}{l}-0.001 \\
(0.008)\end{array}$ & $\begin{array}{c}-0.042^{\star \star \star} \\
(0.009)\end{array}$ & $\begin{array}{c}-0.126^{\star \star \star} \\
(0.023)\end{array}$ & $\begin{array}{c}-0.138^{* * *} \\
(0.018)\end{array}$ & $\begin{array}{c}-0.016^{\star *} \\
(0.007)\end{array}$ & $\begin{array}{c}-0.015^{\star \star \star} \\
(0.004)\end{array}$ & $\begin{array}{l}-0.033^{\star \star \star} \\
(0.008)\end{array}$ & $\begin{array}{c}-0.121^{* * *} \\
(0.017)\end{array}$ & $\begin{array}{l}-0.102^{\star \star \star} \\
(0.019)\end{array}$ & $\begin{array}{c}-0.096^{\star \star *} \\
(0.013)\end{array}$ & $\begin{array}{c}-0.093^{\star \star \star} \\
(0.005)\end{array}$ \\
\hline Age 45-54 & $\begin{array}{l}-0.009 \\
(0.007)\end{array}$ & $\begin{array}{c}-0.043^{\star \star \star} \\
(0.009)\end{array}$ & $\begin{array}{c}-0.115^{\star \star \star} \\
(0.021)\end{array}$ & $\begin{array}{c}-0.180^{\star \star *} \\
(0.017)\end{array}$ & $\begin{array}{c}-0.034^{\star \star \star} \\
(0.007)\end{array}$ & $\begin{array}{c}-0.029^{\star \star *} \\
(0.005)\end{array}$ & $\begin{array}{c}-0.052^{\star \star \star} \\
(0.007)\end{array}$ & $\begin{array}{c}-0.183^{* \star *} \\
(0.015)\end{array}$ & $\begin{array}{c}-0.171^{\star \star *} \\
(0.016)\end{array}$ & $\begin{array}{c}-0.147^{\star \star \star} \\
(0.011)\end{array}$ & $\begin{array}{r}-0.150^{\star \star \star} \\
(0.005)\end{array}$ \\
\hline Age 55-66 & $\begin{array}{l}-0.011 \\
(0.008)\end{array}$ & $\begin{array}{c}-0.030^{\star \star \star *} \\
(0.010)\end{array}$ & $\begin{array}{c}-0.084^{\star \star \star} \\
(0.017)\end{array}$ & $\begin{array}{c}-0.199^{\star \star \star} \\
(0.016)\end{array}$ & $\begin{array}{c}-0.041^{\star \star \star} \\
(0.006)\end{array}$ & $\begin{array}{c}-0.026^{\star \star \star} \\
(0.003)\end{array}$ & $\begin{array}{c}-0.051^{\star \star \star} \\
(0.006)\end{array}$ & $\begin{array}{c}-0.215^{\star \star \star} \\
(0.015)\end{array}$ & $\begin{array}{c}-0.171^{\star \star \star} \\
(0.017)\end{array}$ & $\begin{array}{c}-0.162^{\star \star \star} \\
(0.010)\end{array}$ & $\begin{array}{c}-0.175^{\star \star \star} \\
(0.005)\end{array}$ \\
\hline $\begin{array}{l}\text { Low education } \\
\text { attaintment }\end{array}$ & $\begin{array}{l}-0.015^{\star *} \\
(0.007)\end{array}$ & $\begin{array}{l}-0.010 \\
(0.011)\end{array}$ & $\begin{array}{l}-0.047^{\star *} \\
(0.021)\end{array}$ & $\begin{array}{l}-0.032 \\
(0.026)\end{array}$ & $\begin{array}{c}0.000 \\
(0.013)\end{array}$ & $\begin{array}{c}0.004 \\
(0.016)\end{array}$ & $\begin{array}{l}-0.005 \\
(0.009)\end{array}$ & $\begin{array}{l}-0.014 \\
(0.025)\end{array}$ & $\begin{array}{l}-0.027 \\
(0.036)\end{array}$ & $\begin{array}{l}0.100^{* \star *} \\
(0.034)\end{array}$ & $\begin{array}{c}-0.026^{\star \star \star} \\
(0.009)\end{array}$ \\
\hline $\begin{array}{l}\text { Middle education } \\
\text { attaintment }\end{array}$ & $\begin{array}{l}-0.007 \\
(0.007)\end{array}$ & $\begin{array}{l}-0.010 \\
(0.010)\end{array}$ & $\begin{array}{c}0.022 \\
(0.028)\end{array}$ & $\begin{array}{l}-0.019 \\
(0.019)\end{array}$ & $\begin{array}{c}0.031 \\
(0.019)\end{array}$ & $\begin{array}{l}-0.010 \\
(0.006)\end{array}$ & $\begin{array}{l}-0.019^{\star *} \\
(0.009)\end{array}$ & $\begin{array}{c}-0.052^{* \star *} \\
(0.017)\end{array}$ & $\begin{array}{l}-0.031 \\
(0.023)\end{array}$ & $\begin{array}{l}0.074^{\star \star *} \\
(0.014)\end{array}$ & $\begin{array}{l}-0.002 \\
(0.006)\end{array}$ \\
\hline Unemployed & $\begin{array}{l}0.026 \\
(0.021)\end{array}$ & $\begin{array}{l}-0.008 \\
(0.018)\end{array}$ & $\begin{array}{l}-0.013 \\
(0.038)\end{array}$ & $\begin{array}{l}-0.032 \\
(0.054)\end{array}$ & $\begin{array}{c}0.001 \\
(0.015)\end{array}$ & $\begin{array}{c}0.028 \\
(0.020)\end{array}$ & $\begin{array}{c}0.004 \\
(0.018)\end{array}$ & $\begin{array}{c}0.002 \\
(0.046)\end{array}$ & $\begin{array}{l}-0.073 \\
(0.045)\end{array}$ & $\begin{array}{l}-0.072^{\star \star \star} \\
(0.025)\end{array}$ & $\begin{array}{l}0.024^{* \star *} \\
(0.007)\end{array}$ \\
\hline Disposable income & $\begin{array}{l}0.114^{\star \star} \\
(0.047)\end{array}$ & $\begin{array}{c}0.088 \\
(0.086)\end{array}$ & $\begin{array}{l}-0.399 \\
(0.266)\end{array}$ & $\begin{array}{l}-0.172^{\star \star} \\
(0.078)\end{array}$ & $\begin{array}{c}0.067 \\
(0.102)\end{array}$ & $\begin{array}{c}0.015 \\
(0.031)\end{array}$ & $\begin{array}{l}-0.033 \\
(0.031)\end{array}$ & $\begin{array}{l}0.078 \\
(0.071)\end{array}$ & $\begin{array}{c}0.241 \\
(0.283)\end{array}$ & $\begin{array}{l}-0.199 \\
(0.129)\end{array}$ & $\begin{array}{c}0.012 \\
(0.014)\end{array}$ \\
\hline $\begin{array}{l}\text { Squared disposable } \\
\text { income }\end{array}$ & $\begin{array}{l}-0.005^{\star *} \\
(0.002)\end{array}$ & $\begin{array}{l}-0.004 \\
(0.004)\end{array}$ & $\begin{array}{c}0.020 \\
(0.013)\end{array}$ & $\begin{array}{l}0.010^{\star *} \\
(0.004)\end{array}$ & $\begin{array}{l}-0.003 \\
(0.005)\end{array}$ & $\begin{array}{l}-0.001 \\
(0.002)\end{array}$ & $\begin{array}{c}0.002 \\
(0.002)\end{array}$ & $\begin{array}{l}-0.005 \\
(0.004)\end{array}$ & $\begin{array}{l}-0.011 \\
(0.012)\end{array}$ & $\begin{array}{l}0.011^{*} \\
(0.006)\end{array}$ & $\begin{array}{l}-0.001 \\
(0.001)\end{array}$ \\
\hline $\begin{array}{l}\text { Household living in } \\
\text { cohabitation }\end{array}$ & $\begin{array}{l}-0.001 \\
(0.000)\end{array}$ & $\begin{array}{l}0.001 \\
(0.009)\end{array}$ & $\begin{array}{l}-0.012 \\
(0.024)\end{array}$ & $\begin{array}{l}-0.076^{\star * *} \\
(0.021)\end{array}$ & $\begin{array}{l}0.019^{\star \star *} \\
(0.007)\end{array}$ & $\begin{array}{l}0.018^{* \star \star} \\
(0.005)\end{array}$ & $\begin{array}{c}0.004 \\
(0.009)\end{array}$ & $\begin{array}{c}-0.064^{* * *} \\
(0.017)\end{array}$ & $\begin{array}{l}-0.011 \\
(0.024)\end{array}$ & $\begin{array}{l}-0.003 \\
(0.015)\end{array}$ & $\begin{array}{c}-0.017^{\star \star \star} \\
(0.006)\end{array}$ \\
\hline Foreign citizen & $\begin{array}{l}0.024^{*} \\
(0.015)\end{array}$ & $\begin{array}{l}0.041^{\star *} \\
(0.016)\end{array}$ & $\begin{array}{c}0.026 \\
(0.024)\end{array}$ & $\begin{array}{l}-0.032 \\
(0.035)\end{array}$ & $\begin{array}{l}-0.002 \\
(0.016)\end{array}$ & $\begin{array}{l}. . \\
. .\end{array}$ & $\begin{array}{c}0.027 \\
(0.018)\end{array}$ & $\begin{array}{l}0.007 \\
(0.026)\end{array}$ & $\begin{array}{l}-0.002 \\
(0.025)\end{array}$ & $\begin{array}{l}0.133^{\star \star \star} \\
(0.030)\end{array}$ & $\begin{array}{l}. . \\
. .\end{array}$ \\
\hline Household size & $\begin{array}{l}-0.003 \\
(0.003)\end{array}$ & $\begin{array}{c}-0.012^{\star \star \star} \\
(0.004)\end{array}$ & $\begin{array}{l}-0.012 \\
(0.010)\end{array}$ & $\begin{array}{c}-0.037^{\star \star \star} \\
(0.009)\end{array}$ & $\begin{array}{c}-0.018^{\star \star \star} \\
(0.004)\end{array}$ & $\begin{array}{c}-0.009^{\star \star \star} \\
(0.002)\end{array}$ & $\begin{array}{c}-0.015^{\star \star \star} \\
(0.004)\end{array}$ & $\begin{array}{l}-0.008 \\
(0.008)\end{array}$ & $\begin{array}{c}-0.028^{\star \star \star} \\
(0.010)\end{array}$ & $\begin{array}{c}-0.028^{\star \star \star} \\
(0.006)\end{array}$ & $\begin{array}{c}-0.012^{\star \star \star} \\
(0.002)\end{array}$ \\
\hline Number of observations & 2082 & 11148 & 1793 & 2652 & 2416 & 3395 & 5718 & 3495 & 2525 & 3430 & 28969 \\
\hline
\end{tabular}

1. Estimates from probit regression. Values are marginal effects. The coefficients correspond to the impact of a change in the explanatory variable on the probability to move estimated at the mean of the independent variables. The sample is restricted to individuals who are the head of the household to avoid the results being influenced by atypical tenureship. The estimates are weighted by the individual sampling probability. Regressions further control for dwelling satisfaction. These coefficients are excluded from the table because they are typically non-significant. The regressions include region dummies for the following countries for which the data was available: Australia, Austria, Belgium, Czech Republic, Finland, France, Greece, Hungary, Italy, Spain, Switzerland and United States. Regressions also control for the degree of urbanisation within countries for the sample of European countries from the EU-SILC database. ${ }^{* * *} p<0.01,{ }^{* *} p<0.05,{ }^{*} p<0.1$.

Sources: OECD calculations based on 2007 EU-SILC for European countries, 2007 HILDA for Australia, 2007 SHP for Switzerland and 2007 AHS for United States.

42. Distinguishing between homeowners with a mortgage and outright owners, the larger size of the coefficient on the outright owners relative to the mortgaged owners dummy indicates that those with a mortgage are more mobile. This pattern is clear from Figure 7 that plots the size of the coefficients for the three different tenure type dummies that enter equation (3): outright owners, mortgaged homeowners and social/subsidised housing tenants. A Wald test on the coefficients of the tenure variables for each country confirms that there are significant differences in the tendency to move across tenure types: the coefficients on outright owners, mortgaged homeowners and social/subsidised housing tenants are, overall, significantly different from one another.

43. Indebted homeowners are typically more mobile than outright homeowners (Figure 7). A possible explanation for this finding is that if indebted homeowners' jobs are at risk they have greater incentives to remain employed and to become re-employed more quickly, if needed by moving elsewhere, so as to preserve the ability to repay their mortgage (Flatau et al. 2003). By contrast, in some countries owners with a loan are less mobile than outright owners (Iceland, Norway, United Kingdom, and United States), possibly reflecting negative equity positions that force households to hold on to their housing assets. Ferreira et al. (2008) show that negative equity and higher interest rates tended to lock-in 
homeowners with a mortgage during past housing market declines in the United States, leading to substantial reductions in mobility rates. These findings suggest that the recent collapse in nominal house prices in some countries, coupled with high LTV ratios, may have led to lower residential and labour mobility by pushing a large number of homeowners into negative equity positions,.

Figure 7: Residential mobility and tenure structure ${ }^{1}$

Difference in probability to move relative to tenant in private rental market
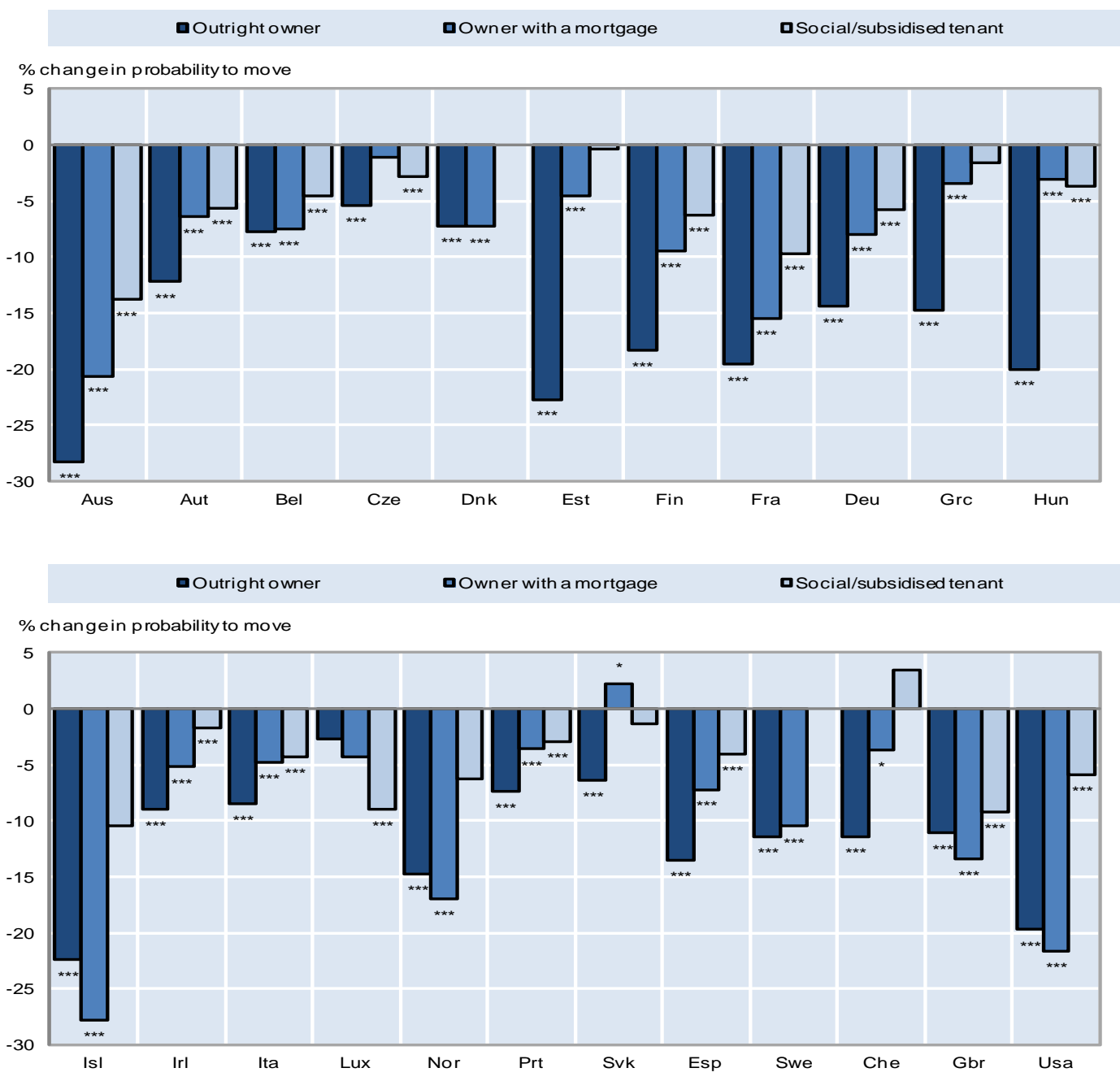

1. The figure shows the percent change in the probability to move of each tenure type relative to private tenants. The results are based on the Prohibit regression of the probability to move as a function of household characteristics estimated country by country. A Wald test of the equality of the coefficients on outright owner, owner with a mortgage and social/subsidised tenant indicates that the parameters are different from each other. ${ }^{* * *}$ denotes statistical significance at $1 \%$, ${ }^{* *}$ denotes statistical significance at $5 \%,{ }^{*}$ denotes statistical significance at $10 \%$.

Sources: OECD calculations based on 2007 EU-SILC Database, on HILDA for Australia, AHS for the United States, SHP for Switzerland. 
44. Residential mobility is lower among households receiving a subsidy or paying below-market rents, compared to private tenants in most countries (Figure 7 and Table 1). ${ }^{12}$ Evidence suggests that compared to tenants in the private rental market, social housing tenants are typically more reluctant to move out so as not to give up their below-market rents (e.g. Flatau et al. 2003). Mobility among social housing tenants is particularly low in countries where social housing is more targeted to those with the greatest need, such as Australia, France and the United Kingdom (Figure 7). In these countries, rents are more controlled in the social than in the private sector and tenants have a higher degree of tenure security ( Andrews et al., 2011), which could explain why social/subsidised tenants are more reluctant to move. On the other hand, targeted social housing systems have the advantage of being means tested (Johansson, 2011); thus, in principle, if similar eligibility criteria are applied across regions these systems could lead to higher tenant mobility because applicants that are eligible for social housing in one region would be eligible in other regions as well.

45. Based on the available data it is difficult to draw a definite conclusion on the effect of social housing systems on mobility. The lower mobility of social/subsidised tenants in countries with highly targeted systems could be also due to reverse causality. Precisely because more targeted systems select people in most need, who may also be the least mobile, mobility could be lower in those countries. Or there could alternatively be a tenant selection effect at work, where low mobility tenants have a stronger incentive to seek rent-controlled housing because their search costs will be amortised over a longer period (Arnott, 1995). To reach a more definitive conclusion one would need to control for the potential reverse causality - for instance, by doing a "difference in difference" analysis. For such an exercise time series data would be necessary.

\section{Other household characteristics and mobility}

46. The negative sign of the coefficients on the age dummies indicates that older households are less mobile than younger ones. This evidence is in line with a large number of studies that find an inverse relationship between age and residential mobility due to life-cycle reasons for moving, such as household formation and increase in household size (e.g. Clark and Withers, 1998). The probability to move also increases with the level of education. More educated households are generally more mobile than lesseducated ones. However, current income and employment status do not generally influence residential mobility, and for a few countries income has a negative effect on mobility, indicating that poorer households are more mobile. ${ }^{13}$ This result seems counter-intuitive if we consider that higher income facilitates the financing of transaction costs involved in moving. However, it may simply indicate that relative to poorer households, richer households have fewer incentives to move in order to satisfy their housing needs.

12 In this study, social/subsidised tenants are tenants whose accommodation is rented at a lower than market price or who are receiving housing allowances. It is, however, difficult to make a clear-cut distinction between social housing and non-social housing tenants based on the available data, because, for instance, in countries such as Sweden or the Netherlands, households living in public housing are likely to be classified in the data as private tenants, despite the fact that public housing is social housing as it is allocated by non-market mechanisms and usually on the basis of need.

There are two possible reasons that may explain the non-significant effect of income on mobility. First, the level of education is a more direct and better measure of lifelong potential earnings influencing housing decisions, as it is less likely to suffer from measurement error and life-cycle bias, than current employment or income. Second, available evidence suggests that although income is important in explaining residential mobility in the owner occupier market, it is actually less important in explaining residential mobility within the rental sector (Van der Vlist et al. 2002). 
47. The negative and significant coefficient on the foreign household dummy indicates that foreign households appear to be somewhat more mobile in some countries than nationals: between $2 \%$ and $13 \%$ respectively more mobile depending on the country. Higher propensity to move among foreign households may reflect lower social attachment and different economic and/or cultural factors (such as ethnic characteristics and minority background) that may make foreign citizens more mobile. Married and larger households are less mobile than single and smaller ones, probably due to higher moving and transaction costs involved when changing residence. By contrast, household satisfaction with the dwelling does not seem to affect the decision to move. Except for very few countries where dissatisfied households are more mobile, the effect of satisfaction is not significant, but this could be due to the potential reverse causality between satisfaction and the mobility decision.

48. A number of potential sources of bias should be mentioned. First, despite the wide set of covariates included in the estimation equation, the results in Table 1 may fail to account for unobserved household characteristics that may influence the decision to move. For instance, households' unobserved characteristics could be correlated with households' observed characteristics included in the vector $\mathrm{H}_{\mathrm{ic}}$ leading to spurious correlation and biased estimates. A possible solution for this problem would be to include household fixed effects in the model to control for household invariant unobserved characteristics. However, given the lack of time series data, this approach is not possible. Secondly, selection bias may be of some concern in the estimation of equation (3) if, for instance, unobserved factors affecting tenure choice are correlated with unobserved factors affecting the probability of moving, so there is a non-random sample of movers. To account for this selection bias, a solution would be to estimate a Heckman selection model, which would involve estimating the probability of moving conditional on tenure choice. However, obtaining credible estimates would require an exclusion restriction: there must be at least one variable that appears in the selection equation and not in the equation of interest. Unfortunately, such variable, that would influence the tenure decision but not the decision to move, is not easy to find based on economic theory. ${ }^{14}$

\subsection{The effect of policy-related factors on residential mobility}

49. Table 2 reports the cross-country results on the effects of different policy-related factors on residential mobility obtained from the estimation of Equation (4). Each column of Table 2 reports alternative specifications of Equation (4) where the policy-related variables enter sequentially, following the same order as in the discussion of the drivers of residential mobility in Section 2. The different specifications control for a similar set of household characteristics as those included in the country-bycountry estimation and for country characteristics that may influence the degree of residential mobility within countries, including income and the degree of urbanisation. ${ }^{15}$ To the extent that some of the policyrelated variables are correlated among themselves (see the correlation matrix reported in the Appendix), these variables are included one at a time so as to avoid multicollinearity problems. The results are, however, robust to including several uncorrelated variables at a time, as shown in the sensitivity checks discussed in the Appendix.

\footnotetext{
$14 \quad$ Credible estimates of a Heckman selection model require at least one variable to appear with a non-zero coefficient in the selection equation and not in the equation of interest. When instead the same covariates appear in the selection equation and the equation of interest, the Heckman selection model bases its identification on the normality assumption, and identification will be tenuous unless there are many observations in the tails where there is substantial non-linearity in the inverse Mills ratio.

Compared to the country-by-country regressions, the cross-country regressions no longer control for foreign citizenship, as such data are not available for the United States and the Slovak Republic.
} 
Table 2: The effect of policy-related factors on residential mobility ${ }^{1}$

\begin{tabular}{|c|c|c|c|c|c|c|c|c|c|c|}
\hline & (1) & (2) & (3) & (4) & (5) & (6) & (7) & (8) & (9) & $(10)$ \\
\hline Policy-related factors & $\begin{array}{l}\text { Transaction } \\
\text { costs buyer }\end{array}$ & $\begin{array}{l}\text { Transaction } \\
\text { taxes }\end{array}$ & Notary fees & Legal fees & Rent control & $\begin{array}{c}\text { Security of } \\
\text { tenure }\end{array}$ & $\begin{array}{c}\text { Elasticity of } \\
\text { supply }^{2}\end{array}$ & $\begin{array}{l}\text { Private credit } \\
\text { to GDP } \\
\text { (2006) }\end{array}$ & Loan to value & $\begin{array}{l}\text { Long term } \\
\text { net } \\
\text { replacement } \\
\text { rates }\end{array}$ \\
\hline \multicolumn{11}{|c|}{ Dependent variable: 1 if head of household changed residence within the past two years, 0 otherwise } \\
\hline Policy-related factors ${ }^{3}$ & $\begin{array}{c}-0.002^{\star \star \star} \\
(0.000)\end{array}$ & $\begin{array}{c}-0.009^{\star \star \star} \\
(0.001)\end{array}$ & $\begin{array}{c}-0.028^{\star \star \star} \\
(0.003)\end{array}$ & $\begin{array}{c}-0.045^{\star \star \star} \\
(0.003)\end{array}$ & $\begin{array}{c}-0.020^{\star * *} \\
(0.002)\end{array}$ & $\begin{array}{c}-0.016^{\star \star \star} \\
(0.003)\end{array}$ & $\begin{array}{c}0.087^{\star \star \star} \\
(0.004)\end{array}$ & $\begin{array}{c}0.031^{\star * *} \\
(0.000)\end{array}$ & $\begin{array}{l}0.002^{* \star *} \\
(0.000)\end{array}$ & $\begin{array}{l}0.001^{\star \star \star} \\
(0.000)\end{array}$ \\
\hline Number of observations & 142162 & 142162 & 133178 & 139025 & 133153 & 138803 & 108394 & 138063 & 139961 & 142162 \\
\hline
\end{tabular}

1. Estimates from probit regression. Values are marginal effects. The coefficients correspond to the impact of a change in the explanatory variable on the probability to move estimated at the mean of the independent variables. Regressions include similar controls as in Table 1, including age, tenureship, education, employment status, income and squared income, cohabitation status, total national income and urbanisation rate, except for foreign citizenship, which is not available for all countries. The sample is restricted to individuals who are the head of the household to avoid the results being influenced by atypical tenureship. The estimates are weighted by the individual sampling probability. Robust standard errors reported in parentheses; ${ }^{\star \star \star}{ }^{*} p<0.01,{ }^{\star \star}{ }^{*} p<0.05,{ }^{*} p<0.1$.

2. Urbanisation rate excluded from (5) because highly correlated with elasticity of supply.

3. The coefficient on private credit to GDP has been scaled by multiplying it by 100 .

Sources: OECD calculations based on 2007 EU-SILC for European countries, 2007 HILDA for Australia, 2007 SHP for Switzerland, 2007 AHS for the United States.

50. Considering the effect of buyer transaction costs on residential mobility, the first column of Table 2 shows that higher transaction costs in buying a property are associated with lower residential mobility. Transaction costs incurred by the buyer are considered because most of the transaction costs involved in a property transaction fall on the buyer rather than the seller (Johansson, 2011). ${ }^{16}$ Decomposing transaction costs into its components shows that transaction taxes, notarial and legal fees have a negative and significant effect on mobility (columns 2, 3 and 4), while real estate and registration fees do not, and for that reason are not reported in the Table. ${ }^{17}$ This evidence is in line with the findings of Van Ommeren and Van Leuvensteijn (2005) for the Netherlands, which suggest that high transaction costs restrict residential mobility, potentially leading to lower labour mobility and higher unemployment, as suggested by Oswald (1996).

51. Higher rent controls, measured by the rent control index, are associated with lower residential mobility. As expected, given the high correlation between rent control and tenant protection (0.62), higher tenant protection is also associated with lower residential mobility. These findings are in line with previous evidence by Lind (2001) and Linneman (1983), among others, who find that turnover rates for households living in rent-controlled dwellings tend to be smaller than for household living in the uncontrolled sector. Despite the fact that these analyses are inconclusive, because they are not causal and do not control for potential selection effects of tenants and landlords, the theoretical and empirical evidence tends to suggest that strict rent regulations are harmful for mobility. ${ }^{18}$ This, in turn, suggests that improving the efficiency

16 This result is robust to considering as an alternative total transaction costs instead of buyer transaction costs under the hypothesis that total transaction costs are likely to be the most relevant for the buyer mobility if seller transaction costs are passed on to the buyer.

17 The compound effect of the individual components of transaction costs on mobility should not be interpreted as the total sum of the components, because the underlying distribution of the transaction costs components varies greatly across countries.

Arnott (1995) argues that evidence of lower turnover rates among tenants living in rent-regulated dwellings could be due to two types of selection effects. First, landlord selection effect as landlords in the controlled sector have an incentive to choose low mobility tenants because low mobility is correlated with stability and responsibility. And second, a tenant selection effect because tenants with a preference for long duration and low mobility self-select into rent-regulated dwellings. 
of rental market regulations may increase residential mobility, particularly in countries where rent controls are high and cover a large segment of the rental market, such as the Netherlands and Sweden. A transition towards a system that strikes a balance between tenants' and landlords' bargaining power and regularly updates rents in line with market developments would encourage mobility.

52. Turning to the role of housing supply, a more responsive supply has a positive and significant effect on residential mobility. The responsiveness of housing supply not only depends on geographical and urban characteristics, but also on regulations on the use of land, as well as on rental regulations, which influence the allocation of land and housing between different uses (Caldera Sánchez and Johansson, 2011). This implies that restrictive regulations, to the extent that they reduce the responsiveness of housing supply to price changes, can hinder household mobility (Mayo and Stein, 1995). For instance, if differences in supply responsiveness give rise to large price differentials across regions, households in lower-priced areas seeking to move to higher-priced regions - possibly to take advantage of better employment prospects - will need to clear a larger credit hurdle than otherwise (Saks, 2008; Barker, 2004; Cameron and Muellbauer, 1998).

53. As discussed above, financial and mortgage markets may affect household mobility through their effects on borrowing costs. Indeed, the results in columns (8) and (9) of Table 2 suggest, that relaxing financial constraints could promote residential mobility. Higher volumes of credit in the economy, as measured by the share of private credit to GDP, appear to enhance residential mobility (Column 8). Higher LTV ratios (the possibility to borrow a larger share of the housing value in order to purchase a home) are also associated with higher residential mobility (Column (9)). These average results may, however, conceal heterogeneous effects of greater availability of credit on residential mobility over the housing cycle. As discussed earlier, high LTV ratios, coupled with decreasing house prices, may have negative effects on residential mobility if households end up into negative equity positions and cannot refinance their loan or raise sufficient capital in order to sell and move to another dwelling (e.g. Ferreira et al. 2008).

54. Labour market institutions are likely to influence household mobility rates. The last column of Table 2 suggests that higher average long-term net unemployment benefit replacement rates are associated with higher residential mobility. Although this finding reflects only the effect of very long-term unemployment benefits on mobility, it is in line with previous findings by Tatsiramos (2009), who finds higher residential mobility in countries with relatively generous benefits, such as Denmark, France and, to some extent, Spain. Thus, by increasing the resources of those unemployed, unemployment benefits may increase residential mobility and help to finance jobseekers' labour moving and search costs. Indeed, OECD (2010) finds that unemployment insurance is associated with higher employment reallocation in OECD countries.

\section{Do policy-related factors affect differently the mobility of young versus old households?}

55. The influence of policy-related factors on residential mobility may vary depending on household characteristics. To obtain deeper insight into this issue, the next step analyses the differential effect of policy-related factors on younger compared with older households. For instance, older households may find it easier to finance the search and transaction costs involved in moving or have greater ability to raise capital in order to finance a new home because of their greater collateral assets than younger households.

56. To investigate these hypotheses the following model is estimated:

$$
\operatorname{Pr}_{i c}=\Phi\left(\alpha+\beta P_{c}+\gamma P_{c} * \text { Old }+\partial O l d+Z_{i c} \phi+C_{c} \Gamma+e_{i c}\right)
$$

where Old is a binary variable taking the value 1 if the head of the household is older than 44 years old, and 0 when is 44 years old or younger, $\mathrm{Z}_{\mathrm{ic}}$ includes the same set of household characteristics as $\mathrm{H}_{\mathrm{ic}}$ in 
equation (4) except that it does not include Old. The coefficient $\gamma$ measures the differential effect of a given policy on old households compared to young ones, while the coefficient $\beta$ measures the average effect of the policy.

Table 3: The effect of policy-related factors on residential mobility of old versus young households ${ }^{1}$

\begin{tabular}{|c|c|c|c|c|c|c|c|}
\hline & (1) & (2) & (3) & $(4)$ & (5) & (6) & (7) \\
\hline Policy-related factors & $\begin{array}{l}\text { Trasaction } \\
\text { costs buyer }\end{array}$ & Rent control & $\begin{array}{c}\text { Security of } \\
\text { tenure }\end{array}$ & $\begin{array}{c}\text { Elasticity of } \\
\text { supply }^{2}\end{array}$ & $\begin{array}{l}\text { Private credit to } \\
\text { GDP (2006) }\end{array}$ & Loan to value & $\begin{array}{c}\text { Long term net } \\
\text { replacement } \\
\text { rates }\end{array}$ \\
\hline \multicolumn{8}{|c|}{ Dependent variable: 1 if head of household changed residence $w$ ithin the past tw o years, 0 otherw ise } \\
\hline Policy-related factors ${ }^{3}$ & $\begin{array}{c}-0.003^{\star \star \star} \\
(0.001)\end{array}$ & $\begin{array}{c}-0.020^{\star \star *} \\
(0.002)\end{array}$ & $\begin{array}{c}-0.018^{\star * *} \\
(0.003)\end{array}$ & $\begin{array}{l}0.035^{\star \star \star} \\
(0.005)\end{array}$ & $\begin{array}{l}0.036^{\star \star \star} \\
(0.000)\end{array}$ & $\begin{array}{l}0.001^{* \star \star} \\
(0.000)\end{array}$ & $\begin{array}{l}0.035^{\star * \star} \\
(0.000)\end{array}$ \\
\hline Policy-related factors * Old & $\begin{array}{c}0.005^{\star \star \star} \\
(0.001)\end{array}$ & $\begin{array}{c}0.010^{\star \star \star \star} \\
(0.002)\end{array}$ & $\begin{array}{l}0.013^{\star *} \\
(0.004)\end{array}$ & $\begin{array}{c}-0.020^{\star \star \star} \\
(0.004)\end{array}$ & $\begin{array}{c}-0.027^{\star * *} \\
(0.000)\end{array}$ & $\begin{array}{c}-0.061^{* * *} \\
(0.000)\end{array}$ & $\begin{array}{c}0.000208 \\
(0.000)\end{array}$ \\
\hline Old & $\begin{array}{c}-0.152^{\star \star \star} \\
(0.006)\end{array}$ & $\begin{array}{c}-0.120^{\star * *} \\
(0.005)\end{array}$ & $\begin{array}{c}-0.134^{\star * \star} \\
(0.010)\end{array}$ & $\begin{array}{c}-0.119^{* * *} \\
(0.006)\end{array}$ & $\begin{array}{c}-0.094^{* * *} \\
(0.009)\end{array}$ & $\begin{array}{c}-0.101^{* * *} \\
(0.011)\end{array}$ & $\begin{array}{c}-0.143^{\star * *} \\
(0.010)\end{array}$ \\
\hline Observations & 142162 & 133153 & 138803 & 108394 & 138063 & 139961 & 142162 \\
\hline
\end{tabular}

1. Estimates from probit regression. Values are marginal effects. The coefficients correspond to the impact of a change in the explanatory variable on the probability to move estimated at the mean of the independent variables. Regressions include similar controls as in Table 1, including age, tenureship, education, employment status, income and squared income, cohabitation status, total national income and urbanisation rate, except for foreign citizenship, which is not available for all countries. The sample is restricted to individuals who are the head of the household to avoid the results being influenced by atypical tenureship. The estimates are weighted by the individual sampling probability. Robust standard errors reported in parentheses, ${ }^{* * *} p<0.01,{ }^{* *} p<0.05,{ }^{*} p<0.1$.

2. Urbanisation rate excluded from (4) because highly correlated with elasticity of supply.

3. The coefficient on private credit to GDP has been scaled by multiplying it by 100 .

Sources: Data over 2007 from EU-SILC for European countries, HILDA for Australia, SHP for Switzerland, AHS for the United States.

57. Estimates of Equation 6 suggest that most policy-related factors have a stronger effect on the mobility of younger households compared to older ones. Transaction costs, rent controls and security of tenure regulations have a negative effect on mobility and their effect is stronger on younger households. An elastic supply, greater access to credit and a relaxation of down-payment constraints is associated with higher residential mobility among younger households compared to older ones. The effect of long-term unemployment protection is, however, not significantly different among younger relative to older households as indicated by the non-significant effect of the interaction between long-term replacement rates and the age dummy.

\subsection{City-level evidence on the effect of policies on residential mobility}

58. The cross-country evidence on the link between housing policies and residential mobility is also supported by an analysis of mobility within the United States, where policies are measured at the city or state level. To the extent that this approach is not affected by unobserved cross-country differences which may be correlated with both mobility patterns and housing policies and it controls for regional differences using region fixed effects, it further strengthens the conclusions drawn from the cross-country analysis.

59. Table 4 reports the results from a probit model of the probability that a household has changed residence within the past two years, as a function of a similar set of policies and controls as in the crosscountry estimation (equation 4). While the underlying household data continue to be drawn from the 2007 American Housing Survey, the policies - which are measured at city and state levels - are obtained from 
various sources. ${ }^{19}$ City-level data on rent controls and land use regulations are drawn from Malpezzi (1996), while state real estate transaction tax rates are obtained from the Federal Tax Administrators Bulletin and the inter-state banking regulation index is from Rice and Strahan (2009). ${ }^{20}$

Table 4: The effect of policies on United States city residential mobility ${ }^{1}$

\begin{tabular}{|c|c|c|c|c|}
\hline & (1) & (2) & (3) & (4) \\
\hline Policies: & Landuse regulation & Rent control & Banking regulation & Transaction tax rate \\
\hline \multicolumn{5}{|c|}{ Dependent variable: 1 if head of household has changed residence $w$ ithin the past tw $o$ years, 0 otherw ise } \\
\hline Policy & $\begin{array}{c}-0.00419^{*} \\
(0.002)\end{array}$ & $\begin{array}{c}-0.0607^{\star \star \star} \\
(0.017)\end{array}$ & $\begin{array}{c}-0.00364^{* \star} \\
(0.002)\end{array}$ & $\begin{array}{c}-0.01 \\
-(0.010)\end{array}$ \\
\hline \multicolumn{5}{|c|}{ Number of observations } \\
\hline & 6720 & 6720 & 6720 & 6720 \\
\hline
\end{tabular}

1. Probit estimates, marginal effects. Regressions include controls for age, tenure status, education, employment status, income, family status, urbanisation, state-level trade union density and regional fixed effects. Robust standard errors reported in parentheses ${ }^{\star * *} \mathrm{p}<0.01,{ }^{* *} \mathrm{p}<0.05,{ }^{*} \mathrm{p}<0.1$.

Sources: OECD calculations based on 2007 American Housing Survey.

60. Results suggest a role for various policies in explaining residential mobility in the United States. The probability that a household changes residence is substantially lower in cities with rent control than in those where rents are determined by market conditions. Residential mobility also tends to be lower in cities with more stringent land-use regulations. The coefficients in Table 4 imply that a one standard deviation rise in the extent of land-use regulation (essentially moving from the regulatory settings in Houston to Los Angeles) reduces the probability of moving by about 10 percentage points, compared to a situation in which land-use regulation is at the sample mean. Higher banking regulation also tends to be associated with lower residential mobility, though this effect is considerably smaller than the impact of land-use regulations. Finally, the last column in Table 4 investigates if higher real estate transaction tax rates at state level tend to reduce residential mobility, but this effect is not significant. ${ }^{21}$

61. Recent research highlights the risk that high leverage can pose to residential mobility. For instance, Ferreira et al. (2008) demonstrate that when house prices decline significantly, residential mobility amongst households in negative equity - i.e. when the value of an outstanding mortgage is greater than the value of the house - falls considerably. This reflects the fact that such households experience difficulties in re-financing their loan - to facilitate a move - or may be unwilling to sell their home and crystallise a loss. Accordingly, the significant increase in the number of households in the United States in negative equity over the last few years (Andrews et al., 2011) has potentially important implications for residential mobility. Figure 8 provides some insight, plotting the change in the state-level mobility rate between 2007 and 2009 against the change in the proportion of households in each state in negative equity over the same period. The chart indicates that residential mobility appears to have fallen more in US states that experienced a larger rise in the share of households in negative equity - such as Nevada - underlining the potential adverse implications of the US housing bust for mobility. Additional econometric modelling not reported for brevity suggests that this relationship is robust to controlling for changes in state-level economic performance and demographic factors.

A caveat of this analysis is that it is based on answers at the city/state of destination. To the extent that the data does not distinguish between inter-city or inter-state moves, the policy settings at the city/state of destination may not be those influencing the decision to move.

The index captures the various regulations that hamper interstate branching, such as limits on banks' size, interstate merger restrictions and restrictions on the amount of deposits a bank can hold.

About two-thirds of US states impose a tax on the transfer of real estate. Unfortunately, no data is available for California, Louisiana or Ohio since transfer taxes are imposed at the local level. 
Figure 8: Residential mobility rate and share of households in negative equity ${ }^{1}$

Percentage point change 2007-2009, United States state-level data

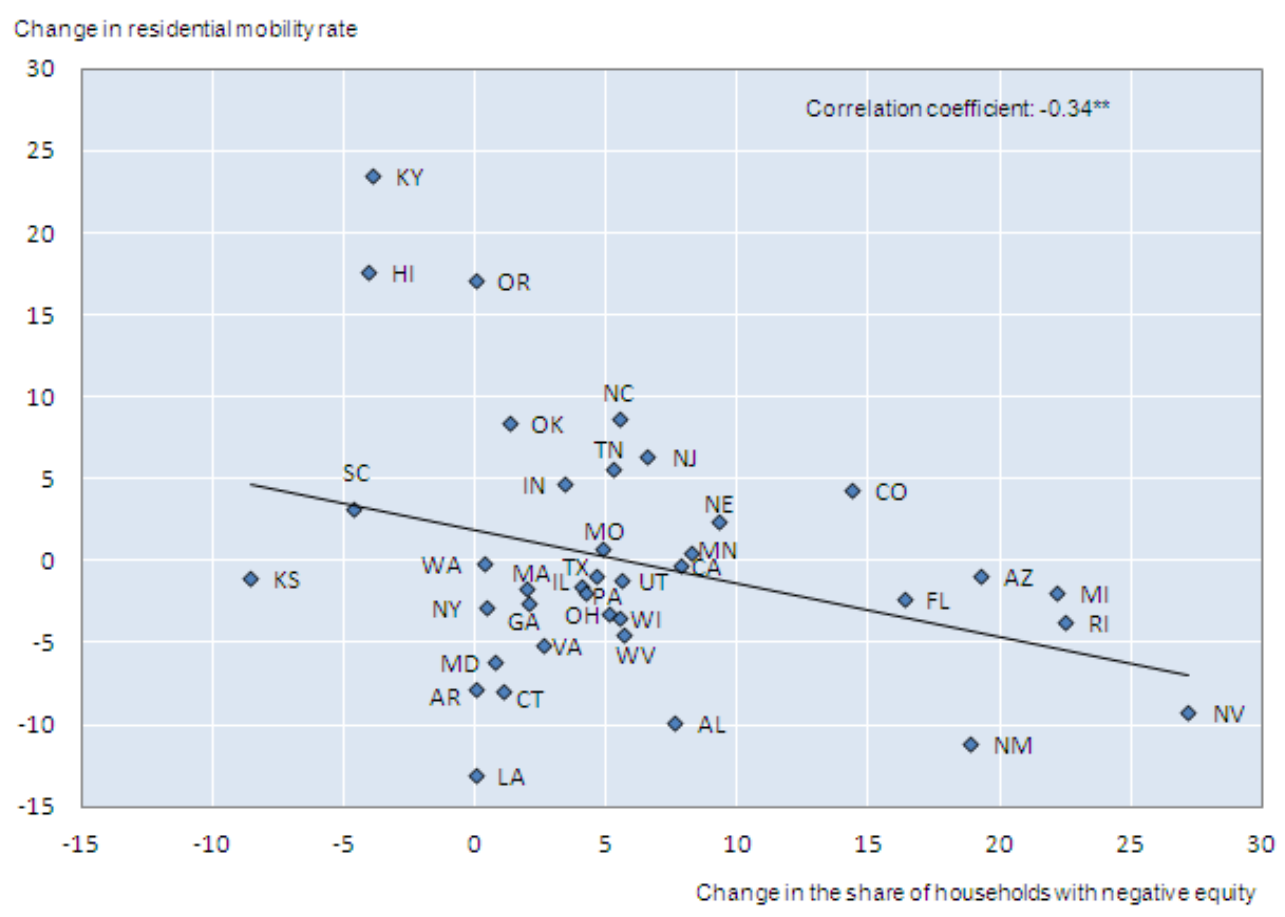

1. Residential mobility rate is measured as the change in the two-year mobility rate between the 2007 and 2009.

Source: OECD calculations based on American Housing Survey (AHS).

\section{Economic significance of the effect of policy-related factors on mobility}

62. To understand the economic significance of the effect of policy-related factors on residential mobility and the improvements in residential mobility that could be associated with policy reforms, Figure 9 shows how different policy scenarios influence residential mobility based on the estimates in Table 2 . Each dot is the average probability to move evaluated at average policy and household characteristics. The distance between the minimum/maximum and the average is the change in probability associated with a policy change. ${ }^{22}$

63. Reducing transaction costs could increase residential mobility: The evidence in Figure 9 suggests that reducing overall transaction costs from the highest level observed in Belgium to the average level observed in Austria would bring an increase in residential mobility of about 1 percentage point. Transfer taxes are the most important component of transaction costs in most countries (Johansson, 2011). Lowering transfer taxes from the highest level observed in Greece (14\%) to the average level observed in the Netherlands $(3 \%)$ would increase residential mobility by about 6 percentage points. This would represent a very large policy change equivalent to $41 / 4$ standard deviations drop in transaction costs, which perhaps is unrealistic. A more moderate change from the level observed in Ireland (4.5\%) to the average level, equivalent to about 1 standard deviation drop, would increase residential mobility by about 1.5 percentage points.

22 The reported probabilities are computed at the mean, max or min of the policy variables and at the mean of the rest of explanatory variables. 
Figure 9: Residential mobility and policy-related factors ${ }^{1}$

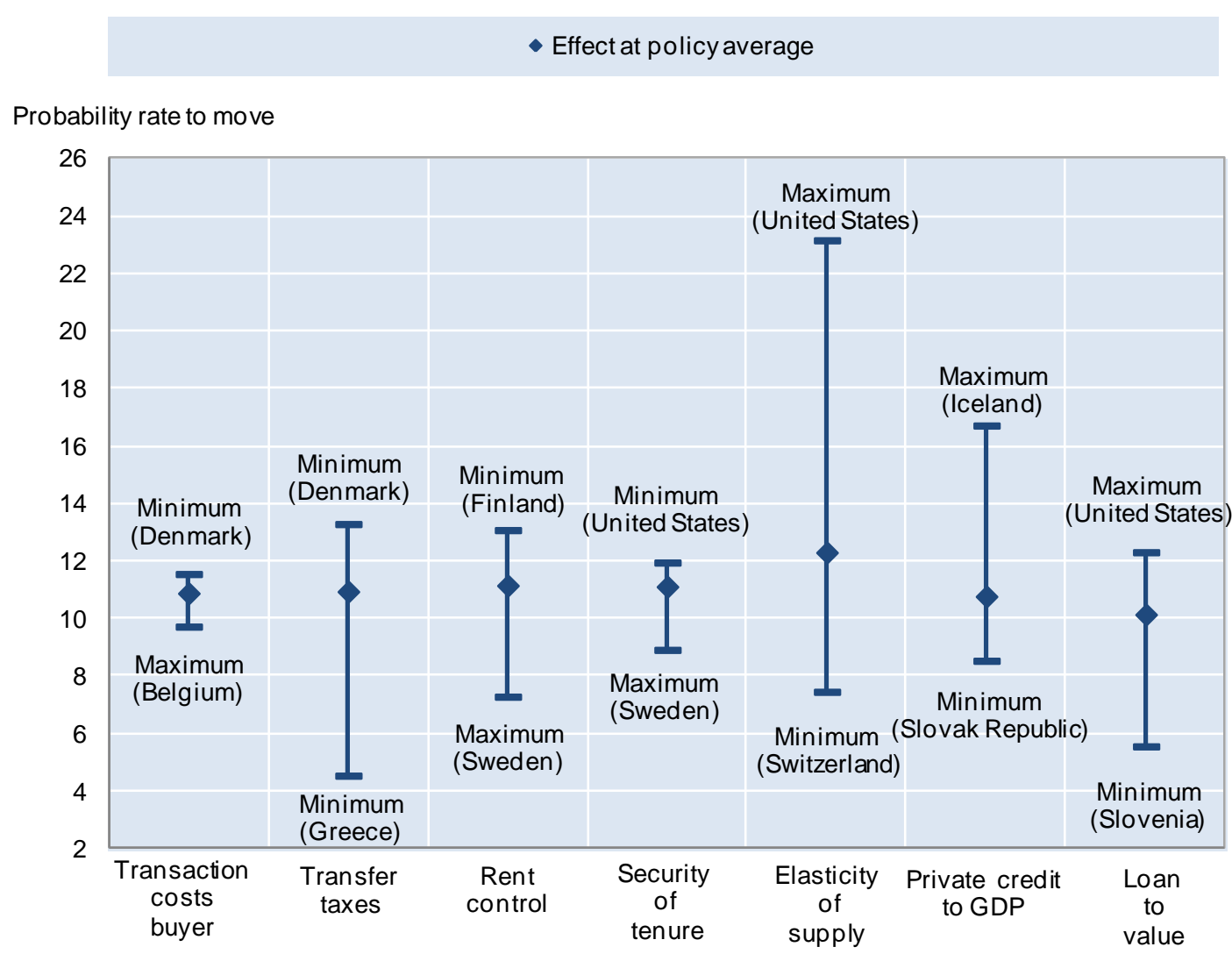

1. The dot is the average probability to move evaluated at average policy and household characteristics. The distance between the Min/Max and the average is the change in the probability associated with a policy change. The reported probabilities for the elasticity of supply and loan to value have a different mean than the other specifications because they are estimated on a reduced sample of countries due to data constraints. Based on the estimates presented in Table 2.

Sources: OECD calculations based on 2007 EU-SILC Database, on HILDA for Australia, SHP for Switzerland and AHS for the United States.

64. Reducing rent controls and changing the bargaining power balance between tenants and landlords could increase residential mobility: Reducing rent controls from the level in the most restrictive country (Switzerland) to that of the average country (e.g. Norway) could increase residential mobility by about 4 percentage points - an increase of about 35\%. Making the rules governing tenant-landlord relations more landlord-friendly, by easing them from the level in the most restrictive country (Sweden) to the average (e.g. Denmark) could increase residential mobility by about 2 percentage points, an increase of $20 \%$.

65. An irresponsive housing supply tends to undermine residential mobility: Regression estimates suggest that an increase in the responsiveness of supply in the country with the least responsive supply (Switzerland) to the average (e.g. Ireland) would be associated with almost double average residential mobility.

66. Easier access to credit can ease financial constraints and improve residential mobility: Finally, increasing the volume of private credit to GDP in the economy from the lowest level observed in the Slovak Republic, to the average level (Sweden), could increase residential mobility by 2 percentage points, i.e. approximately $30 \%$. Similarly, by lowering down-payment constraints (or increasing LTV ratios) from the lowest level in Slovenia (50 loan-to-value) to the average (e.g. Estonia 90) could increase average residential mobility by 5 percentage points, an increase of about $60 \%$. 


\section{REFERENCES}

Andrews, D. and A. Caldera Sánchez and Å. Johansson. (2011), "Housing markets and structural policies in OECD countries", OECD Economics Department Working Papers no. 836, OECD, Paris.

Arnott, R. (2003), “Tenancy Rent Control”, Swedish Economic Policy Review, Vol. 10.

Arnott, R. (1995), “Time for Revisionism on Rent control?”, Journal of Economic Perspectives 9, pp. 99120.

Barker, K. (2004), “Barker Review of Housing Supply” HM Treasury, United Kingdom, http://www.barkerreview.org.uk/ .

Bartel, A. P. (1979), “The Migration Decision: What Role Does Job Mobility Play?", American Economic Review, 1979, Vol. 69, Issue 5, pp. 775-86.

Bassanini, A. and R. Duval (2006), "Employment Patterns in OECD Countries: Reassessing the Role of Policies and Institutions", OECD Social, Employment and Migration Working Papers No. 35.

Bassanini, A, A. Garnero, P. Marianna and S. Martin (2010), "Institutional Determinants of Worker Flows: a Cross-Country/Cross Industry Approach", OECD Social, Employment and Migration Working Papers, OECD Publishing, Paris.

Blanchard, O. and L. F. Katz (1992), "Regional Evolutions" Brookings Papers on Economic Activity, 1, pp. 1-75.

Blanchard, O. and J. Wolfers (2000), "The Role of Shocks and Institutions in the Rise of European Unemployment: The Aggregate Evidence", Economic Journal, Royal Economic Society, vol. 110(462), pages C1-33.

Bloze, G. (2009), "Interregional Migration and Housing Structure in an East European Transition Country: A view of Lithuania 2001-2008”, Baltic Journal of Economics 9 (2), pp. 47-66.

Bover, O., J. Muellbauer, and A. Murphy (1989), "Housing, Wages and UK Labour Markets", Oxford Bulletin of Economics and Statistics, Department of Economics, University of Oxford, vol. 51(2), pages 97-136, March.

Boeri, T. and K. Terrell (2002), "Institutional Determinants of Labour Reallocation in Transition", Journal of Economic Perspectives, 16(1), pp. 51-76.

Cameron, G. and J. Muellbauer (1998), 'The Housing Market and Regional Migration and Community Choices', Scottish Journal of Political Economy.

Caldera Sánchez, A. and ̊, Johansson (2011) “The Price Responsiveness of Housing Supply in OECD Countries", OECD Economics Department Working Papers no. 837, OECD, Paris. 
Chan, S. (2001), “Spatial Lock-in: Do Falling House Prices Constrain Residential Mobility?”, Journal of Urban Economics 49, pp. 567-586.

Coulson, N.E. and L.M. Fisher (2009). "Housing Tenure and Labour Market Impacts: The Search Goes On”, Journal of Urban Economics, 65, Issue 3, pp. 252-264.

Cunningham, C.R. and G. Engelhardt (2007), "Housing Capital-Gains Taxation and Homeowner Mobility: Evidence from the Taxpayer Relief Act of 1997”, Journal of Urban Economics 63 (2008) pp. 803-815.

Clark, W.A.V. and S. Davies Withers (1999), "Changing Jobs and Changing Houses: Mobility Outcomes of Employment Transitions", Journal of Regional Science, 39(4), pp. 653-673.

Clark, W.A.V., A. Heskin, and D. Allan (1982), "The Impact of Rent Control on Tenure Discounts and Residential Mobility”, Land Economics, Vol. 58, No. 1 (Feb., 1982), pp. 109-117.

David, Q., A. Janiak and E. Wasmer (2010), "Local Social Capital and Geographical Mobility”, forthcoming Journal of Urban Economics.

Decressin J. and A. Fatas (1995), "Regional Labour Market Dynamics in Europe", European Economic Review 39(9): pp. 1627-55.

Dieleman, F.M. (2001), "Modelling Residential Mobility: a Review of Recent Trends in Research", Journal of Housing and the Built Environment, 16: pp. 249-265.

ECB (2009), “Housing Finance and Monetary Policy”, Working Paper Series No. 1069.

Englund, P., and Y.M. Ioannides (1993), "The Dynamics of Housing Prices: an International Perspective", In: Bos, D. (Ed.), Economics in a Changing World. Macmillan, NY, pp. 175-197.

Ersing, R. L., R.D. Sutphen and D.N. Loeffler (2009), "Exploring the Impact and Implications of Residential Mobility: From the Neighbourhood to the School", Advances in Social Work, Vol. 10 No. 1 (Spring), pp. 1-18.

European Housing Review (2009), RICS Royal Institution of Chartered Surveyors.

Fack, G. and J. Grenet (2010), "When do Better Schools Raise Housing Prices? Evidence from Paris Public and Private Schools", Journal of Public Economics. Vol. 94, Issues 1-2, pp. 59-77.

Ferreira, F., J. Gyurko and J. Tracy (2008), "Housing Busts and Household Mobility”, NBER Working Paper Series 14310.

Fidrmuc, J. (2004), "Migration and Regional Adjustment to Asymmetric Shocks in Transition Economies", Journal of Comparative Economics, Vol. 32, Issue 1, pp. 230-247.

Flatau, M. F., P.H. Hendershott and G.Wood (2003), "Homeownership and Unemployment: The Roles of Leverage and Public Housing", NBER Working Paper No. 10021.

Gibbons, S. and S. Machin (2003), "Valuing English Primary Schools”, Journal of Urban Economics, 53 (2), pp. 197-219. 
Gibbons, S. and S. Machin (2006), "Paying for Primary Schools: Supply Constraints," School Popularity or Congestion", The Economic Journal, Vol. 116(510).

Green, R.K. and P.H. Hendershott (2001), "Home Ownership and the Duration of Unemployment: A Test of the Oswald Hypothesis", Working Paper, University of Aberdeen.

Hardman, A.M., Y.M. Ioannides (1999), "Residential Mobility, and the Housing Market in a Two-Sector Neoclassical Growth Model”, Scandinavian Journal of Economics 101, pp. 315-335.

Hassler J, J. Mora, K. Storesletten and F. Zilibotti (2005), “A Positive Theory of Geographical Mobility and Social Insurance", International Economic Review 46(1): pp. 263-303.

Henley, A. (1996), "Residential Mobility, Housing Equity and the Labour Market” Economic Journal, 108, pp. 414-427.

Hughes, G. and B. McCormick (1997),"Housing Markets Unemployment and Labour Markets Flexibility in the United Kingdom”, European Economic Review 31 (1987), pp. 615-645.

Hughes, G. and B. McCormick (1985), "Migration Intentions in the U.K. Which Households Want to Migrate and Which Succeed?", The Economic Journal, Vol. 95, Supplement: Conference Papers (1985), pp. 113-123.

Hughes, G. and B. McCormick(1981), "Do Council Housing Policies Reduce Migration between Regions?” The Economic Journal, 91 (December 1981), pp 919-937.

Janiak, A. and E. Wasmer (2008), "Mobility in Europe-Why is it Low, the Bottlenecks and the Policy Solutions", European Economy, Economic and Financial Affairs Directorate General, European Commission.

Johansson, Å. (2011), "Housing Policies in OECD Countries: Survey-based Data and Implications", OECD Economics Department Working Papers, OECD, Paris, forthcoming.

Lind, H (2001), "Rent Regulation: A Conceptual and Comparative Analysis", International Journal of Housing Policy, Vol. 1 (1), pp. 41-57.

Linneman, P. (1983), "Resource Distribution Effects of New York City Rent Controls" NBER Working Paper No. 9-83.

Malpezzi, S. (1996), "Housing prices, externalities, and regulation in U.S. metropolitan areas", Journal of Housing Research 7(2): 209-241.

Mayo, S. K. and J.I. Stein (1985), "Housing and Labour Market Distortions in Poland: Linkages and Policy Implications", Journal of Housing Economics No. 4, pp. 153-182.

Menard, S. and F. Sellem (2010), "How Does Social Housing Affect the Rate of Equilibrium Unemployment?", unpublished mimeo TEPP-GAINS.

Mincer, J. (1978), "Family Migration Decisions," The Journal of Political Economy, Vol. 86, No. 5, pp. 749-773.

Oswald, A.J. (1996), "A Conjecture on the Explanation for High Unemployment in the Industrialized Nations: Part I”, Warwick University Economic Research Paper No. 475. 
Oswald, A.J. (1999), “The Housing Market and Europe's Unemployment: A Non-Technical Paper”, Mimeo, University of Warwick.

Rice, T. and P.E. Strahan (2009), “Does Credit Competition Affect Small-Firm Finance?” Journal of Finance, Forthcoming.

Rupert, P. and E. Wasmer (2009), “ Housing and the Labour Market : Time to Move and Aggregate Umemployment”, IZA Discussion Paper No. 4172.

Saks, R, (2008), "Job Creation and Housing Construction: Constraints on Metropolitan Area Employment Growth", Journal of Urban Economics, Vol. 64 (1), 178-195.

Sinai, T. (1998), “Taxation, User Cost, and Household Mobility Decisions”, Working Paper No. 303. Wharton School, University of Pennsylvania.

Sims, D. (2007), "Out of Control: What Can We Learn from the End of Massachusetts Rent Control?", Journal of Urban Economics, 2007, Vol. 1.

Sjaastad, L. (1962), “The Costs and Returns of Human Migration,” Journal of Political Economy 70, pp. 80-89.

Tatsiramos, K. (2009), “Geographic Labour Mobility and Unemployment Insurance in Europe”, Journal of Population Economics, 22: pp. 267-283.

Van der Vlist, A.J., C. Gorter, P. Nijkamp and P. Rietveld (2002) "Residential Mobility and Local Housing Market Differences", Tinbergen Institute Discussion Papers, No 02-003/3.

Van Ommeren J. and M. Van Leuvensteijn (2005), "New Evidence of the Effect of Transaction Costs on Residential Mobility", Journal of Regional Science, Vol. 45. 


\section{APPENDIX 1: SENSITIVITY CHECKS}

\section{Large country bias}

67. The cross-country results reported in Table 2 are based on pooled household data samples for different countries. The country-level datasets have different sample sizes owing to different population sizes and household survey designs across countries. To test the sensitivity of the results to the potential bias introduced by pooling together country samples of different sizes, and to see whether the results are driven by countries with large samples, the cross-country equation (4) is estimated on pooled country samples of equal size.

68. To construct equally- sized country samples we draw random samples of the original country samples restricting the sample sizes to that of the smallest country sample. Table $2 \mathrm{~A}$ shows that the results are not sensitive to large countries sample bias. The results based on the reduced samples are in line with the baseline results reported in Table 2. Restricting the country samples to different sizes does neither influence the size and significance of the results nor its implications (See Tables 3A and 4A).

\section{Including several policies in the cross-country model}

69. In the analysis of the effect of policies on residential mobility the effect of each policy on residential mobility was investigated by including each policy in the regression one by one. To verify that the results are robust to considering the simultaneous effects of various policies, the following set of results includes several policies in the regression equation. To avoid multicollinearity problems only those variables that are not significantly correlated are included.

70. Table 1A reports the correlation matrix among the different policies, while Table 5A reports the results of different regressions, including several groupings of policies. The results are generally robust to this test and lead to similar conclusions as in the baseline results. Transaction costs, rent control and tenure security regulations have a negative effect on residential mobility. The responsiveness of supply, loan-tovalue ratios, private credit and long-term net replacement rates have a positive effect on mobility. But, the effect of long-term net replacement rates and loan-to-value ratios is sensitive to the considered specification. In columns (3), (4), (5) of Table 5A the coefficients on those variables are not significant. 
ECO/WKP(2011)15

Table 1A. Correlation between different policies and policy related factors

\begin{tabular}{|c|c|c|c|c|c|c|c|}
\hline & (1) & (2) & (3) & (4) & (5) & (6) & (7) \\
\hline Policies & $\begin{array}{l}\text { Transaction } \\
\text { costs buyer }\end{array}$ & Rent control & $\begin{array}{l}\text { Security of } \\
\text { tenure }\end{array}$ & $\begin{array}{c}\text { Elasticity of } \\
\text { supply }\end{array}$ & $\begin{array}{l}\text { Private credit to } \\
\text { GDP (2006) }\end{array}$ & Loan to value & $\begin{array}{c}\text { Long term net } \\
\text { replacement } \\
\text { rates }\end{array}$ \\
\hline Transaction costs buyer & 1.00 & & & & & & \\
\hline Rent control & -0.03 & 1.00 & & & & & \\
\hline Security of tenure & 0.31 & 0.62 & 1.00 & & & & \\
\hline Elasticity of supply & -0.54 & -0.40 & -0.51 & 1.00 & & & \\
\hline Private credit to GDP (2006) & -0.58 & -0.23 & -0.59 & 0.59 & 1.00 & & \\
\hline Loan to value & -0.05 & -0.37 & -0.23 & 0.39 & 0.17 & 1.00 & \\
\hline Long term net replacement rates & 0.29 & -0.35 & -0.14 & 0.02 & 0.07 & 0.09 & 1.00 \\
\hline
\end{tabular}

Sources: OECD calculations based on 2007 EU-SILC for European countries, 2007 HILDA for Australia, 2007 SHP for Switzerland and 2007 AHS for the United States.

Table 2A. Sensitivity check: Large country bias, country sample size equal to Portugal ${ }^{1}$

(smallest sample size)

\begin{tabular}{|c|c|c|c|c|c|c|c|c|c|c|}
\hline & (1) & (2) & (3) & (4) & (5) & (6) & (7) & (8) & (9) & (10) \\
\hline Policy-related factors & $\begin{array}{l}\text { Transaction } \\
\text { costs buyer }\end{array}$ & $\begin{array}{l}\text { Transaction } \\
\text { taxes }\end{array}$ & Notary fees & Legal fees & Rent control & $\begin{array}{c}\text { Security of } \\
\text { tenure }\end{array}$ & $\begin{array}{l}\text { Easticity of } \\
\text { supply }^{2}\end{array}$ & $\begin{array}{l}\text { Private credit to } \\
\text { GDP (2006) }\end{array}$ & Loan to value & $\begin{array}{l}\text { Long term net } \\
\text { replacement } \\
\text { rates }\end{array}$ \\
\hline \multicolumn{11}{|c|}{ Dependent variable: 1 if head of household changed of residence $w$ ithin the past tw o years, 0 otherw ise } \\
\hline Policy-related factors ${ }^{3}$ & $\begin{array}{c}-0.002^{* * *} \\
(0.001)\end{array}$ & $\begin{array}{c}-0.005^{* \star *} \\
(0.001)\end{array}$ & $\begin{array}{c}-0.026^{* * *} \\
(0.005)\end{array}$ & $\begin{array}{c}-0.046^{* * *} \\
(0.005)\end{array}$ & $\begin{array}{c}-0.017^{* * *} \\
(0.003)\end{array}$ & $\begin{array}{l}-0.012^{* * *} \\
(0.004)\end{array}$ & $\begin{array}{l}0.074^{* * *} \\
(0.006)\end{array}$ & $\begin{array}{l}0.013^{* * *} \\
(0.000)\end{array}$ & $\begin{array}{l}0.001^{* * *} \\
(0.000)\end{array}$ & $\begin{array}{l}0.001^{* * *} \\
(0.000)\end{array}$ \\
\hline Number of observations & 59230 & 59230 & 54189 & 56795 & 51787 & 56559 & 37175 & 56617 & 57029 & 59230 \\
\hline
\end{tabular}

1. Estimates from probit regression. Values are marginal effects. The coefficients correspond to the impact of a change in the explanatory variable on the probability to move estimated at the mean of the independent variables. Regressions include similar controls as in Table 1, including age, tenureship, education, employment status, income and squared income, cohabitation status, total national income and urbanisation rate, except for foreign citizenship, which is not available for all countries. The sample is restricted to individuals who are the head of the household to avoid the results being influenced by atypical tenureship. The estimates are weighted by individual sampling probability. Robust standard errors in parentheses. ${ }^{\star \star *} p<0.01,{ }^{* *}$ $\mathrm{p}<0.05,{ }^{*} \mathrm{p}<0.1$.

2. Urbanisation rate excluded from (5) because highly correlated with elasticity of supply.

3. The coefficient on private credit to GDP has been scaled by multiplying it by 100 .

Sources: OECD calculations based on 2007 EU-SILC for European countries, 2007 HILDA for Australia, 2007 SHP for Switzerland, 2007 AHS for the United States. 


\section{ECO/WKP(2011)15}

Table 3A. Sensitivity check: large country bias, country sample size equal to Luxembourg ${ }^{1}$

(second smallest sample size)

\begin{tabular}{|c|c|c|c|c|c|c|c|c|c|c|}
\hline & (1) & (2) & (3) & (4) & (5) & (6) & (7) & (8) & (9) & (10) \\
\hline Policy-related factors & $\begin{array}{l}\text { Transaction } \\
\text { costs buyer }\end{array}$ & $\begin{array}{l}\text { Transaction } \\
\text { taxes }\end{array}$ & Notary fees & Legal fees & Rent control & $\begin{array}{c}\text { Security of } \\
\text { tenure }\end{array}$ & $\begin{array}{l}\text { Easticity of } \\
\text { supply }^{2}\end{array}$ & $\begin{array}{l}\text { Private credit } \\
\text { to GDP } \\
\text { (2006) }\end{array}$ & Loan to value & $\begin{array}{c}\text { Long term net } \\
\text { replacement } \\
\text { rates }\end{array}$ \\
\hline \multicolumn{11}{|c|}{ Dependent variable: 1 if head of household changed of residence $w$ ithin the past tw 0 years, 0 otherw ise } \\
\hline Policy-related factors ${ }^{3}$ & $\begin{array}{l}-0.002^{\star *} \\
(0.001)\end{array}$ & $\begin{array}{c}-0.006^{\star \star \star} \\
(0.001)\end{array}$ & $\begin{array}{c}-0.022^{\star \star \star} \\
(0.005)\end{array}$ & $\begin{array}{c}-0.045^{\star \star \star} \\
(0.005)\end{array}$ & $\begin{array}{c}-0.016^{\star \star \star} \\
(0.002)\end{array}$ & $\begin{array}{l}-0.008^{\star *} \\
(0.004)\end{array}$ & $\begin{array}{l}0.063^{* \star *} \\
(0.006)\end{array}$ & $\begin{array}{l}0.013^{* \star *} \\
(0.000)\end{array}$ & $\begin{array}{l}0.001^{* * *} \\
(0.000)\end{array}$ & $\begin{array}{l}0.000^{* *} \\
(0.000)\end{array}$ \\
\hline Number of observations & 64341 & 64341 & 58843 & 61687 & 56419 & 61431 & 40603 & 61492 & 62140 & 64341 \\
\hline
\end{tabular}

1. Estimates from probit regression. Values are marginal effects. The coefficients correspond to the impact of a change in the explanatory variable on the probability to move estimated at the mean of the independent variables. Regressions include similar controls as in Table 1, including age, tenureship, education, employment status, income and squared income, cohabitation status, total national income and urbanisation rate, except for foreign citizenship, which is not available for all countries. The sample is restricted to individuals who are the head of the household to avoid the results being influenced by atypical tenureship. The estimates are weighted by the individual sampling probability. Robust standard errors in parentheses. ${ }^{* \star \star}$ $p<0.01,{ }^{* \star} p<0.05,{ }^{*} p<0.1$.

2. Urbanisation rate excluded from (5) because highly correlated with elasticity of supply.

3. The coefficient on private credit has been scaled by multiplying it by 100 .

Sources: OECD calculations based on 2007 EU-SILC for European countries, 2007 HILDA for Australia, 2007 SHP for Switzerland, 2007 AHS for the United States. 
ECO/WKP(2011)15

Table 4A. Sensitivity check: large country bias, country sample size equal to Switzerland ${ }^{1}$

(third smallest sample size)

\begin{tabular}{|c|c|c|c|c|c|c|c|c|c|c|}
\hline & (1) & (2) & (3) & (4) & (5) & (6) & (7) & (8) & (9) & $(10)$ \\
\hline Policy-related factors & $\begin{array}{l}\text { Transaction } \\
\text { costs buyer }\end{array}$ & $\begin{array}{c}\text { Transaction } \\
\text { taxes }\end{array}$ & Notary fees & Legal fees & Rent control & $\begin{array}{c}\text { Security of } \\
\text { tenure }\end{array}$ & $\begin{array}{c}\text { Easticity of } \\
\text { supply }^{2}\end{array}$ & $\begin{array}{l}\text { Private credit } \\
\text { to GDP (2006) }\end{array}$ & Loan to value & $\begin{array}{l}\text { Long term net } \\
\text { replacement } \\
\text { rates }\end{array}$ \\
\hline \multicolumn{11}{|c|}{ Dependent variable: 1 if head of household changed of residence $w$ ithin the past tw 0 years, 0 otherw ise } \\
\hline Policy-related factors ${ }^{3}$ & $\begin{array}{l}-0.001^{*} \\
(0.001)\end{array}$ & $\begin{array}{c}-0.006^{* * *} \\
(0.001)\end{array}$ & $\begin{array}{c}-0.017^{\star * \star} \\
(0.005)\end{array}$ & $\begin{array}{l}-0.048^{\star \star *} \\
(0.005)\end{array}$ & $\begin{array}{c}-0.012^{* * *} \\
(0.002)\end{array}$ & $\begin{array}{l}-0.004 \\
(0.004)\end{array}$ & $\begin{array}{l}0.060^{\star \star *} \\
(0.006)\end{array}$ & $\begin{array}{l}0.025^{\star \star} \\
(0.000)\end{array}$ & $\begin{array}{l}0.001^{\star * *} \\
(0.000)\end{array}$ & $\begin{array}{l}0.000^{\star *} \\
(0.000)\end{array}$ \\
\hline Number of observations & 64990 & 64990 & 59428 & 62308 & 57025 & 62063 & 41089 & 62123 & 62789 & 64990 \\
\hline
\end{tabular}

1. Estimates from probit regression. Values are marginal effects. The coefficients correspond to the impact of a change in the explanatory variable on the probability to move estimated at the mean of the independent variables. Regressions include similar controls as in Table 1, including age, tenureship, education, employment status, income and squared income, cohabitation status, total national income and urbanisation rate, except for foreign citizenship, which is not available for all countries. The sample is restricted to individuals who are the head of the household to avoid the results being influenced by atypical tenureship. The estimates are weighted by the individual sampling probability. Robust standard errors in parentheses. ${ }^{* \star \star}$ $p<0.01,{ }^{* *} p<0.05,{ }^{*} p<0.1$.

2. Urbanisation rate excluded from (5) because highly correlated with elasticity of supply.

3. The coefficient on private credit to GDP has been scaled by multiplying it by 100 .

Sources: OECD calculations based on 2007 EU-SILC for European countries, 2007 HILDA for Australia, 2007 SHP for Switzerland, 2007 AHS for the United States. 


\section{ECO/WKP(2011)15}

Table 5A. Sensitivity check: including several policies in the cross-country model ${ }^{1}$

(2)

(3)

(4)

(5)

Dependent variable: 1 if head of household changed of residence $w$ ithin the past tw 0 years, 0 otherw ise

\begin{tabular}{|c|c|c|c|c|c|}
\hline Transaction costs buyer & $\begin{array}{l}-0.003^{\star \star \star} \\
(0.000)\end{array}$ & $\begin{array}{l}-0.003^{\star \star \star} \\
(0.000)\end{array}$ & $\begin{array}{l}. . \\
. .\end{array}$ & $\begin{array}{l}. . \\
. .\end{array}$ & $\begin{array}{l}. . \\
. .\end{array}$ \\
\hline Rent control & $\begin{array}{c}-0.015^{\star * *} \\
(0.002)\end{array}$ & .. & $\begin{array}{c}-0.029^{\star * *} \\
(0.003)\end{array}$ & $\begin{array}{c}-0.029^{* * *} \\
(0.003)\end{array}$ & $\begin{array}{r}-0.020^{* \star \star} \\
(0.002)\end{array}$ \\
\hline Security of tenure & .. & $\begin{array}{c}-0.017^{\star * *} \\
(0.003)\end{array}$ & $\begin{array}{l}. . \\
. .\end{array}$ & .. & $\begin{array}{l}. . \\
. .\end{array}$ \\
\hline Easticity of supply & .. & $\begin{array}{l}. . \\
. .\end{array}$ & $\begin{array}{l}0.080^{* * *} \\
(0.005)\end{array}$ & $\begin{array}{l}0.080^{* * *} \\
(0.005)\end{array}$ & $\begin{array}{l}. . \\
. .\end{array}$ \\
\hline Loan to value & $\begin{array}{l}0.001^{\star * *} \\
(0.000)\end{array}$ & $\begin{array}{l}0.001^{* * *} \\
(0.000)\end{array}$ & $\begin{array}{c}0.000 \\
(0.000)\end{array}$ & $\begin{array}{c}0.000 \\
(0.000)\end{array}$ & .. \\
\hline $\begin{array}{l}\text { Long term net replacement } \\
\text { rates }\end{array}$ & $\begin{array}{l}0.000^{\star \star} \\
(0.000)\end{array}$ & $\begin{array}{l}0.001^{\star * *} \\
(0.000)\end{array}$ & $\begin{array}{l}-0.000 \\
(0.000)\end{array}$ & $\begin{array}{l}-0.000 \\
(0.000)\end{array}$ & $\begin{array}{l}-0.000 \\
(0.000)\end{array}$ \\
\hline Private credit to $\operatorname{GDP}(2006)^{2}$ & $\begin{array}{l}. . \\
. .\end{array}$ & $\begin{array}{l}. . \\
. .\end{array}$ & $\begin{array}{l}. . \\
. .\end{array}$ & $\begin{array}{l}. . \\
. .\end{array}$ & $\begin{array}{l}0.045^{\star *} \\
(0.000)\end{array}$ \\
\hline Number of observations & 133153 & 136602 & 108394 & 108394 & 129054 \\
\hline
\end{tabular}

1. Estimates from probit regression. Values are marginal effects. The coefficients correspond to the impact of a change in the explanatory variable on the probability to move estimated at the mean of the independent variables. The sample is restricted to individuals who are the head of the household to avoid the results being influenced by atypical tenureship. The estimates are weighted by the individual sampling probability. Regressions include similar controls as in Table 1, including age, tenureship, education, employment status, income and squared income, cohabitation status, total national income and urbanisation rate, except for foreign citizenship, which is not available for all countries. Robust standard errors in parentheses, ${ }^{\star \star *} \mathrm{p}<0.01$, ${ }^{\star \star}$ $p<0.05,{ }^{*} p<0.1$.

2. The coefficient on private credit to GDP has been scaled by multiplying it by 100 .

Sources: OECD calculations based on data over 2007 from EU-SILC for European countries, HILDA for Australia, SHP for Switzerland, AHS for the United States. 


\section{WORKING PAPERS}

The full series of Economics Department Working Papers can be consulted at www.oecd.org/eco/workingpapers/

845. Reforming the labour market in Spain

(February 2011) by Anita Wölfl and Juan S. Mora-Sanguinetti

844. Macroeconomic Impact of Basel III

(February 2011) by Patrick Slovik and Boris Cournède

843. The policy and institutional drivers of economic growth across OECD and non-OECD economies: new evidence from growth regressions

by Romain Bouis, Romain Duval, and Fabrice Murtin

842. Limiting Long-Term Unemployment and Non-Participation in Sweden (February 2011) by Niels-Jakob Harbo Hansen

841. Enhancing the cost-effectiveness of climate change mitigation policies in Sweden (February 2011) by Stéphanie Jamet

840. Policies towards a sustainable use of water in Spain (February 2011) by Andrés Fuentes

839. Increasing public sector efficiency in Slovakia (January 2011) by Felix Hüfner

838. Raising education outcomes in Switzerland (January 2011) by Andrés Fuentes

837. The Price Responsiveness of Housing Supply in OECD Countries (January 2011) by Aida Caldera Sánchez and Åsa Johansson

836. Housing markets and structural policies in OECD countries (January 2011) by Dan Andrews, Aida Caldera Sánchez and Åsa Johansson

835. Raising potential growth after the crisis: A quantitative assessment of the potential gains from various structural reforms in the OECD area and beyond (January 2011) by Romain Bouis and Romain Duval

834. The GDP impact of reform: a simple simulation framework (January 2011) by Sebastian Barnes, Romain Bouis, Philippe Briard, Sean Dougherty and Mehmet Eris

833. Improving the flexibility of the Dutch housing market to enhance labour mobility (January 2011) by Jens Høj

832. Making the Dutch pension system less vulnerable to financial crises (January 2011) by Jens Høj 
831. Real house prices in OECD countries: the role of demand shocks and structural policy factors

(December 2010) by Dan Andrews

830. International financial integration and the external positions of euro area countries (December 2010) by Philip R. Lane

829. Improving fiscal performance through fiscal councils (December 2010) by Robert Hagemann

828. Minimising risks from imbalances in European banking (December 2010) by Sebastian Barnes, Philip Lane and Artur Radziwill

827. Resolving and avoiding unsustainable imbalances (December 2010) by Sebastian Barnes

826. Current account imbalances in the euro area: a comparative perspective (December 2010) by Sebastian Barnes, Jeremy Lawson and Artur Radziwill

825. Does fiscal decentralisation strengthen social capital? Cross-country evidence and the experiences of Brazil and Indonesia

(December 2010) by Luiz de Mello

824. Fiscal decentralisation and public investment: The experience of Latin America (December 2010) by Luiz de Mello

823. Product market regulation and competition in China (December 2010) by Paul Conway, Richard Herd, Thomas Chalaux, Ping He and Jianxun Yu

822. Reforming China's monetary policy framework to meet domestic objectives (December 2010) by Paul Conway, Richard Herd and Thomas Chalaux

821. Regulatory reforms to unlock long-term growth in Turkey (December 2010) by Rauf Gönenç and Łukasz Rawdanowicz

820. After the crisis: mitigating risks of macroeconomic instability in Turkey (December 2010) by Łukasz Rawdanowicz

819. The 2008-09 crisis in Turkey: performance, policy responses and challenges for sustaining the recovery

(December 2010) by Łukasz Rawdanowicz

818. Fiscal-consolidation strategies for Canadian governments (November 2010) by Yvan Guillemette

817. The land transport sector: policy and performance (November 2010) by Jan Persson and Daeho Song 